\title{
A revised interpretation of Cambrian and Ordovician rocks in the Bourinot belt of central Cape Breton Island, Nova Scotia
}

\author{
Chris E. White1, Sandra M. Barr1, Mary Lou Bevier2 and Sandra Kamo3 \\ IDepartment of Geology, Acadia University, Wolfville, Nova Scotia B0P IXO, Canada \\ 2 Department of Geological Sciences, University of British Columbia, \\ 6339 Stores Road, Vancouver, British Columbia V6T 2B4, Canada \\ 3Royal Ontario Museum, 100 Queen's Park, Toronto, Ontario M5S 2C6, Canada
}

Date Received February 14, 1994

Date Accepted July 25, 1994

\begin{abstract}
New U-Pb (zircon) data from the northern Boisdale Hills show that rhyolite on Long Island and syenogranite of the nearby Mount Cameron pluton have similar ages of $505 \pm 3 \mathrm{Ma}$ and $509 \pm 2 \mathrm{Ma}$, respectively. These ages are similar to those known or inferred from some felsic plutonic units elsewhere in central Cape Breton Island and suggest that latest Cambrian to earliest Ordovician igneous activity was widespread in the Bras d'Or terrane. The new dates also suggest that stratigraphic and structural relationships in the Boisdale Hills are more complex than previously interpreted.

The dated rhyolite and other volcanic and sedimentary rocks in the northern Bourinot belt in the Boisdale Hills were previously included in undivided Middle Cambrian Bourinot Group. In the southern Bourinot belt, the Bourinot Group was subdivided into the Eskasoni, Dugald, and Gregwa formations. The Eskasoni Formation is dominantly a bimodal volcanic suite with petrological characteristics indicative of origin in a continental within-plate tectonic setting. Its present contacts, both with adjacent older metamorphic and plutonic rocks and with the apparently overlying fossiliferous Dugald and volcanogenic Gregwa formations, are faulted. Our new mapping demonstrates that the Eskasoni, Dugald and Gregwa formations can be extended into the central Bourinot belt where they were previously undivided. However, continuity cannot be demonstrated between these Middle Cambrian units and the dated volcanic and associated sedimentary units in the northern Bourinot belt. Hence, assuming that both U-Pb and fossil ages are correct, our interpretation is that the Upper Cambrian Lower Ordovician Northern Boisdale Hills volcanic unit is younger than the Bourinot Group, although petrochemical data suggest that it formed in a similar tectonic regime.

The presence in the Bourinot belt of fauna characteristic of the Acado-Baltic faunal province appears to tie the Bras d'Or terrane to other Avalonian (peri-Gondwanan) terranes. However, the Bras d'Or terrane differs from the adjacent Mira terrane which includes Lower as well as Middle and Upper Cambrian units and lacks volcanic and plutonic rocks of this age.
\end{abstract}

De nouvelles données U-Pb (zircon) provenant de la partie nord des collines Boisdale montrent que la rhyolite sur l'île Long et le syénogranite du pluton du mont Cameron à proximité ont des âges similaires, de $505 \pm 3 \mathrm{Ma}$ et $509 \pm 2 \mathrm{Ma}$ respectivement. Ces âges sont similaires à ceux connus ou supposés pour quelques unités plutoniques felsiques ailleurs dans le centre de l'île-du-Cap-Breton, et suggèrent que l'activité ignée de la fin du Cambrien au début de l'Ordovicien était répandue dans le terrain de Bras d'Or. Ces nouvelles datations suggèrent aussi que les relations stratigraphiques et structurales dans les collines Boisdale sont plus complexes que ne le montraient les interprétations antérieures.

La rhyolite datée et d'autres roches volcaniques et sédimentaires de la partie nord de la ceinture de Bourinot dans les monts Boisdale étaient auparavant incluses dans le Groupe de Bourinot non divisé, du Cambrien moyen. Dans la partie sud de la ceinture de Bourinot, le Groupe de Bourinot était divisé en formations d'Eskasoni, de Dugald et de Gregwa. La Formation d'Eskasoni est principalement une suite volcanique bimodale avec des caractéristiques pétrologiques indiquant un environnement tectonique intracontinental. Ses contacts actuels, à la fois avec les roches métamorphiques et plutoniques plus vieilles et avec les formations apparemment susjacentes de Dugald, fossilifere, et de Gregwa, volcanique, sont faillés. Notre nouvelle cartographie montre que les formations d'Eskasoni, de Dugald et de Gregwa peuvent être distinguées dans le centre de la ceinture de Bourinot où elles ne l'étaient pas auparavant. Toutefois, on ne peut pas démontrer de continuité entre ces unités du Cambrien moyen et les volcanites datées et les unités sédimentaires associées dans la partie nord de la ceinture de Bourinot. Ainsi, en assumant que les âges U-Pb et paléontologiques sont corrects, notre interprétation est que cette unité volcanique du Cambrien tardif - Ordovicien inférieur du nord des collines Boisdale soit plus jeune que le Groupe de Bourinot, quoique les données pétrologiques suggèrent qu'elle se soit formée dans un environnement tectonique similaire.

La présence dans la ceinture de Bourinot de fossiles caractéristiques de la province faunique acado-baltique semble relier le terrain de Bras d'Or aux autres terrains avaloniens (péri-Gondwana). Toutefois, le terrain de Bras d'Or diffêre du terrain adjacent de Mira qui comprend des unités du Cambrien inférieur autant que moyen et supérieur et ne présente pas de roches volcaniques et plutoniques de cet âge.

[Traduit par la rédaction] 


\section{INTRODUCTION}

Cambrian-Ordovician volcanic and sedimentary rocks in the Boisdale Hills occur in a narrow, northeast-trending belt more than $30 \mathrm{~km}$ in length and only $3 \mathrm{~km}$ in maximum width (Fig. 1). This belt, here termed the Bourinot belt, mainly occupies a valley between ridges of older metamorphic and plutonic units. The presence of Cambrian-Ordovician rocks in the Bourinot belt has been known since the work of Fletcher (1877) and Matthew (1903), but the most definitive study was completed by Hutchinson (1952). He presented a stratigraphic subdivision based mainly on fossil evidence that subsequently became widely accepted. The fossils in the Bourinot belt have Acado-Baltic (Henningsmoen, 1969) or Avalonian (Landing, 1994) affinity, considered indicative of the Avalon zone, including southern Cape Breton Island, southeastern Newfoundland and southern New Brunswick (Hutchinson, 1952, 1962; Williams, 1979).

More recently, the presence of Cambrian-Ordovician rocks with Acado-Baltic fauna in the Bourinot belt has been used to support the interpretation that all of Cape Breton Island is part of an Avalon Composite Terrane, amalgamated by the late Precambrian (Keppie, 1990; Keppie and Dallmeyer, 1991; Landing, 1991; Murphy et al., 1990). In contrast, Barr and Raeside (1989) proposed that the area is part of the Bras d'Or terrane and separate from Avalon terrane sensu stricto, as represented by the Mira terrane of southeastern Cape Breton Island. Barr et al. (1990) suggested that the boundary between the Bras d'Or and Mira terranes is located beneath Devonian and Carboniferous cover units in the area between the Boisdale and Coxheath hills (Fig. 1). They suggested that the Cambrian-Ordovician rocks of the Bourinot belt might be allochthonous (derived from the Mira terrane) and that juxtaposition of the Bras d'Or and Mira terranes may have taken place as late as the Devonian.

This paper reports new observations based on detailed mapping in the Bourinot belt, combined with U-Pb dates for zircon from a rhyolite flow on Long Island and from the Mount Cameron syenogranite (Fig. 1), as well as new petrochemical data from igneous units. We present a modified interpretation of the distribution and stratigraphic relationships of units compared to that of Hutchinson (1952). Furthermore, the new U-Pb ages suggest that volcanic rocks in the northern part of the Bourinot belt are younger than, and hence not correlative with, those in the south. These rocks are assigned to a new unit informally called the Northern Boisdale Hills volcanic unit. Overall, geological relationships in the Bourinot belt are much more complex than suggested by the previously accepted stratigraphic model, and the belt is unlikely to be an allochthonous part of the Mira terrane.

\section{MaP units in the Bourinot belT}

\section{Introduction}

On the basis of palaeontology and lithology, Hutchinson (1952) subdivided the rocks of the Bourinot belt into formal units consisting of the Middle Cambrian Bourinot Group (Eskasoni, Dugald and Gregwa formations), the Middle Cam- brian MacMullin Formation, the Upper Cambrian MacNeil Formation, and the Lower Ordovician McLeod Brook Formation. The first three formations were considered mappable as separate units only in the Indian River (southern) part of the belt (Fig. 2). In the central and northern parts of the belt, rocks assumed to be correlative with these three formations were combined as undivided Bourinot Group. In addition to the areas described by Hutchinson (1952), Weeks (1954) also recognized a small area of Bourinot Group rocks southwest of Eskasoni (Fig. 1).

The rocks of the Bourinot belt are described below, including the units defined by Hutchinson (1952), the newly recognized Northern Boisdale Hills volcanic unit, and the Long Island metamorphic unit. Although not of Cambrian-Ordovician age, the latter unit is included because it has not been examined or described in any detail by earlier workers.

\section{Eskasoni Formation}

As defined by Hutchinson (1952), the Eskasoni Formation is a unit of mainly volcanic rocks in the Indian River area, with the type section on Gregwa Brook (Fig. 2). Matthew (1903, 1915) had correlated these rocks with the basal part of the Cambrian system and, by comparison with the Coldbrook volcanic rocks in southern New Brunswick which he considered to be similar, referred to them as the Coldbrook terrane. However, the Coldbrook volcanic rocks in New Brunswick are now known to be Precambrian (e.g., Bevier and Barr, 1990; Barr et al., 1992), whereas the Eskasoni Formation appears to be of Middle Cambrian age. The latter age interpretation is based on the apparent stratigraphic position of the formation below the fossiliferous Middle Cambrian Dugald Formation (see below) and on the reported presence of a thin fossiliferous tuffaceous shale bed containing Middle Cambrian brachiopods and ostracodes in Dugald Brook (Matthew, 1903, 1915; Walcott, 1912). However, the shale bed was not found during the present study.

The Eskasoni Formation was reported to overlie Precambrian metasedimentary rocks unconformably (Matthew, 1903, 1915; Hutchinson, 1952). However, based on the widespread occurrence of slickensides and tectonic breccias in the volcanic rocks, and local development of cleavage, we interpret the contact to be everywhere faulted, although the nature and magnitude of the fault displacements are unknown. If abundant mafic dykes in the adjacent Shunacadie Pluton (Barr and Setter, 1986) represent feeders to the mafic flows of the Eskasoni Formation, the amount of offset may not be large.

The Eskasoni Formation in Gregwa and Dugald brooks and adjacent areas (Fig. 2) consists of interlayered basaltic and rhyolitic flows with minor felsic lithic lapilli tuff. The basalts are locally amygdaloidal, in places with elliptical, mainly calcitefilled amygdales up to $2 \mathrm{~cm}$ in maximum diameter. The formation is missing in MacMullin Brook, where granite of the $c a$. 564 Ma Shunacadie Pluton (Barr et al., 1990) appears to be in faulted contact with the Gregwa Formation (Fig. 2). Small faultbounded(?) areas of volcanic rocks occur in Gillis Brook and near an unnamed brook farther north (Fig. 2). North of this area, outcrop is sparse but only granitoid rocks appear to be present. 


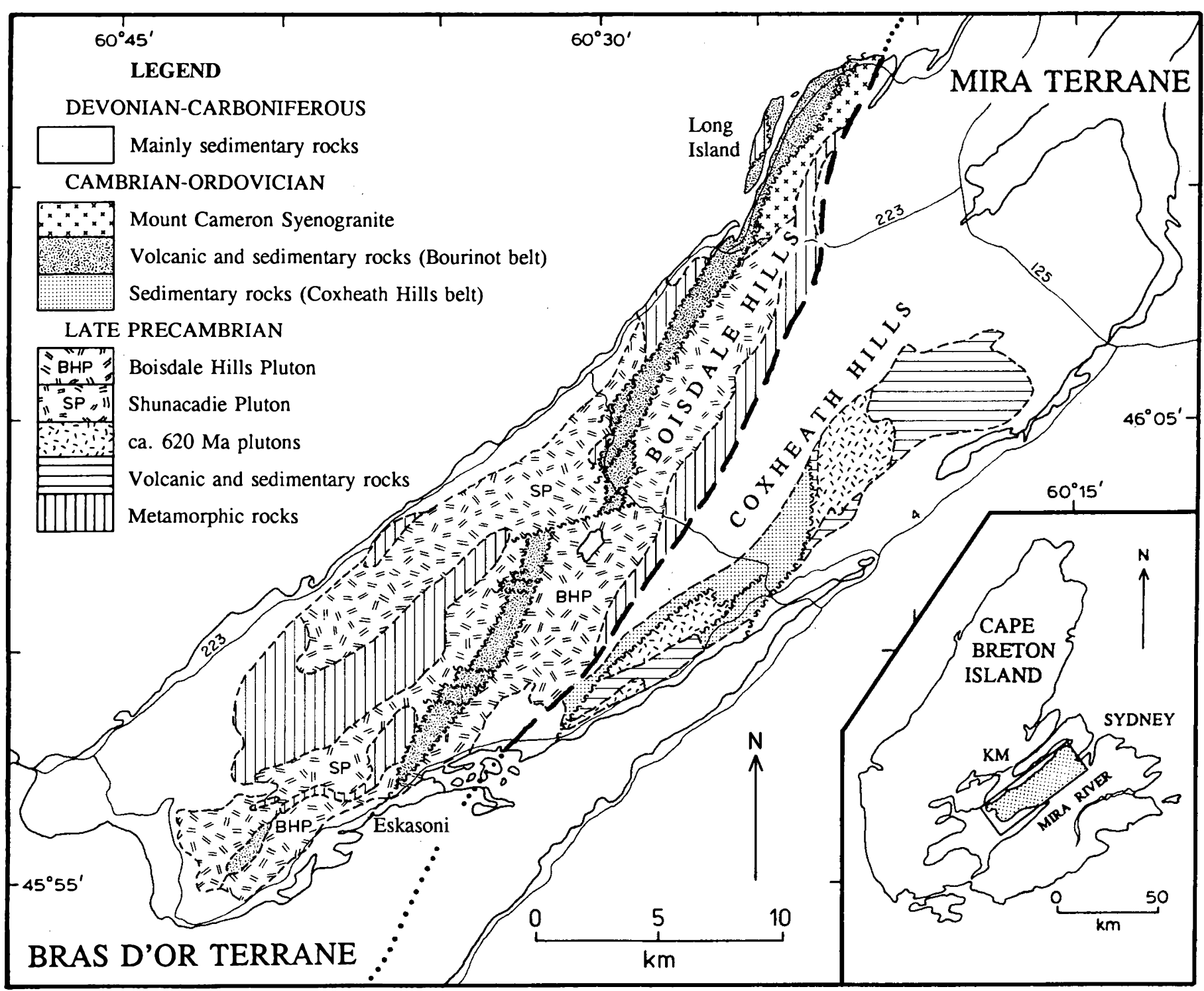

Fig. 1. Geological map of the Boisdale Hills, showing the location of the Bourinot belt. Modified from Raeside and Barr (1990).

In the small area of Cambrian rocks southwest of Eskasoni (Fig. 1), amygdaloidal basalts, probably of the Eskasoni Formation, unconformably overlie gneissic rocks of unknown age. Also present are quartz arenite and brown siltstone with black inarticulate brachiopods, which are assigned to the overlying Dugald Formation (see below).

In the Bourinot Road area (central Bourinot belt, Fig. 3), Hutchinson (1952) did not consider it possible to separate the volcanic rocks (Eskasoni Formation) from overlying Dugald and Gregwa formations (Hutchinson, 1952, p. 8). However, our mapping indicated the distribution of units shown on Figure 3. In this area, the Eskasoni Formation is dominantly basaltic, with minor lapilli tuff and intraformational boulder conglomerate. Clasts in the tuff and in the conglomerate are mainly of rhyolitic composition, but no rhyolite flows were observed in this area. The basaltic rocks can be traced via sparse outcrops along the northwestern side of the valley of McLeod Brook, where they appear to occur in narrow fault-bounded slivers (Figs. $3,4)$.

\section{Dugald Formation}

Hutchinson (1952, p. 11) assigned the name "Dugald Formation" to a sequence of "quartzitic siltstones and silty, tuffaceous shales" which he interpreted to overlie the Eskasoni Formation conformably. The type section was established by Hutchinson (1952) in Dugald Brook (Fig. 2). The formation appears to have been faulted out in several areas, including MacMullin Brook where both it and the Eskasoni Formation are missing (Fig. 2). Although Hutchinson (1952) did not separate the Dugald Formation from the Bourinot Group in the Bourinot Road area, rocks typical of the unit are exposed in a major tributary of McLeod Brook (Fig. 3).

Walcott (1912) and Hutchinson (1952) assigned an early Middle Cambrian age to the Dugald Formation based on the presence of inarticulate brachiopods and rare trilobites. The lower contact of the Dugald Formation with volcanic rocks of the Eskasoni Formation is exposed in Gregwa and Dugald brooks and the upper western tributary of McLeod Brook. Matthew 


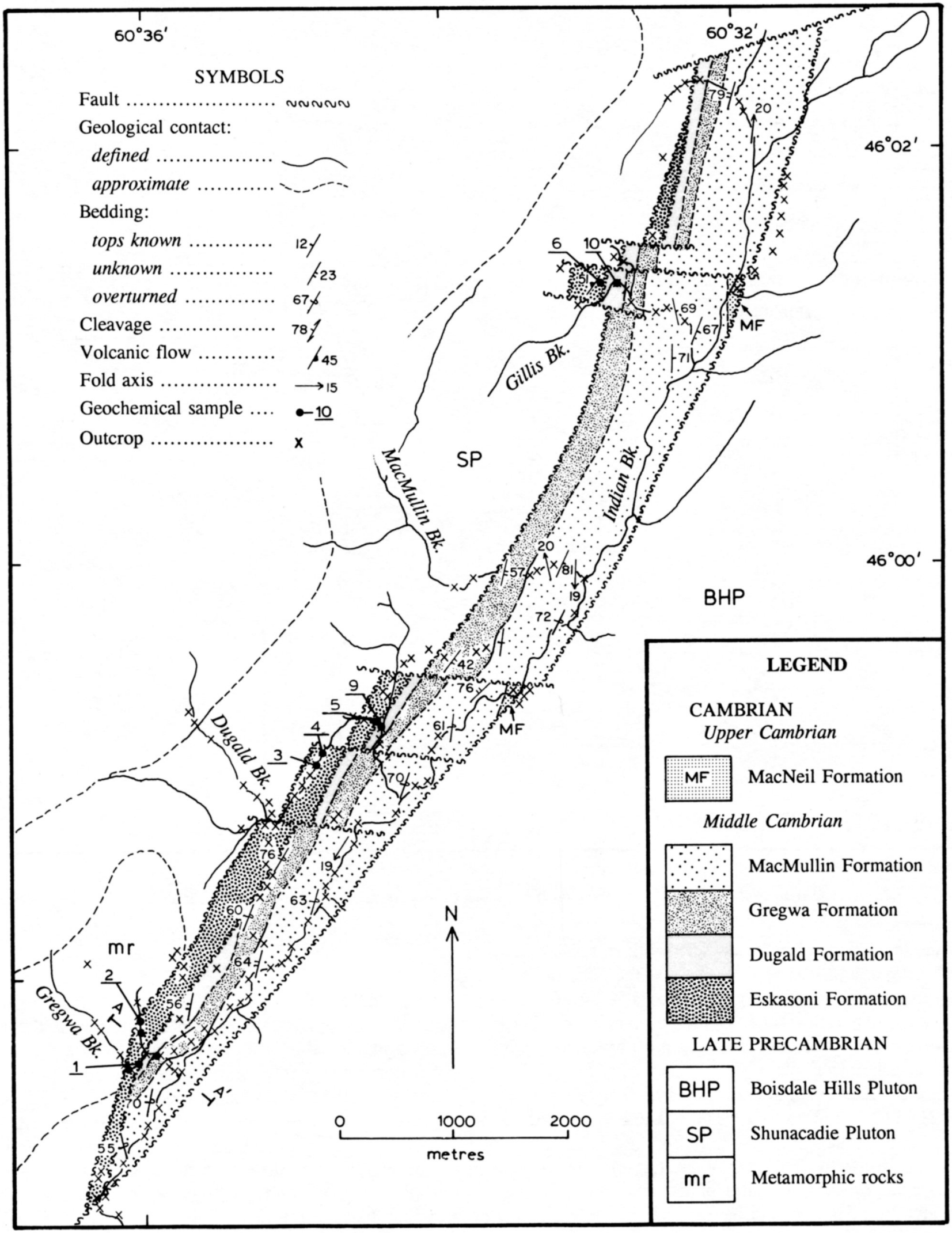

Fig. 2. Geological map of the southern (Indian River) part of the Bourinot belt. Cross-section A-A' is shown in Figure 7. Unnumbered geochemical sample locations are from Cameron (1980) and Murphy et al. (1985).

(1903) considered this contact to be disconformable, whereas Hutchinson (1952) inferred a gradual lithological transition between the two units. Our observations indicate that the contact is everywhere faulted and marked by a sharp increase in topography typically occupied by a waterfall in stream sections. We attribute the absence of the Dugald Formation in some sections 


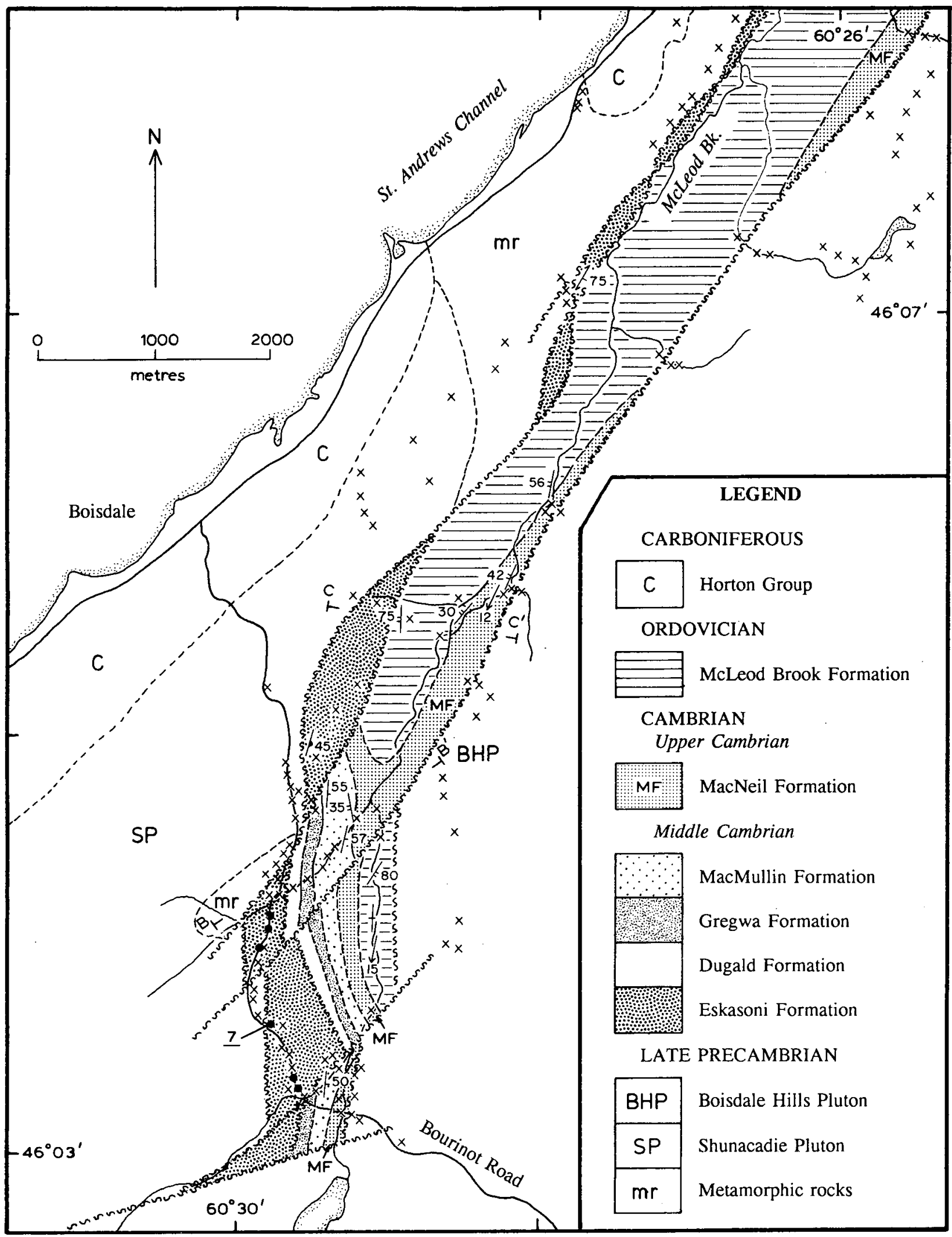

Fig. 3. Geological map of the central (Bourinot Road) part of the Bourinot belt, with symbols as in Figure 2. Cross-sections B-B' and C-C' are shown in Figure 7.

(e.g., MacMullin Brook) to faulting rather than lateral facies change as suggested Hutchinson (1952).

The Dugald Formation consists mainly of interbedded, locally micaceous, brown to maroon and grey to green siltstone, green and red shaly siltstone, fine-grained sandstone, and arkosic to feldspathic wacke with minor volcanic rock fragments. Sedimentary structures such as horizontal laminations, cross-bedding and "rip-up" features are common. Small, black inarticu- 


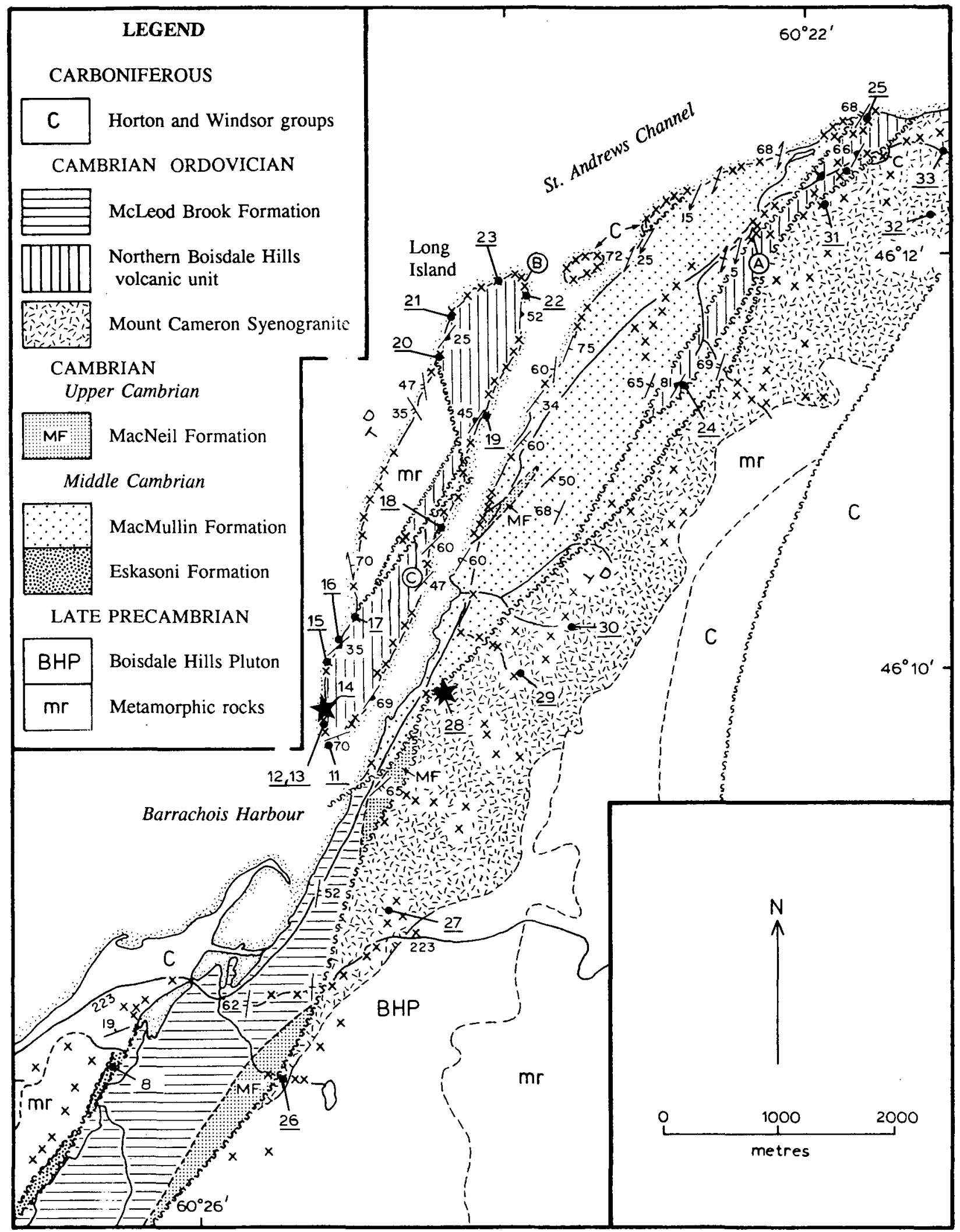

Fig. 4. Geological map of the northern part of the Bourinot belt, with symbols as in Figure 2. Cross-section D-D' is shown in Figure 7. Particular features at localities A, B and C are described in the text. Stars indicate locations of dated samples.

late brachiopod shells on bedding planes are characteristic of some siltstone layers. Thin beds $(<2-3 \mathrm{~cm}$ thick) of pale grey to cream-coloured chert locally occur in the upper part of the formation. Rare beds ( $<20 \mathrm{~cm}$ thick) of red and green, fine-grained volcanogenic conglomerate occur throughout the formation. A distinctive component of the formation near its base is a unit of white coarse quartz arenite and conglomerate. Hutchinson $(1952$, p. 12) wrote that these "distinctive white quartzites" are 
exposed only on Gillis Brook, but we found them also in Gregwa and Dugald brooks, and in an unnamed brook north of Gillis Brook, as well as in the area southwest of Eskasoni (Fig. 1). The quartz arenite consists of rounded quartz grains (> 95\%), with minor amounts of feldspar, mica, opaque minerals, allanite, amphibole and zircon. Lithic clasts in conglomeratic facies of the unit include rhyolite-dacite, siltstone and mylonitic quartzite. In places, the rhyolite-dacite clasts are dominant. Overall, a granitic and felsic volcanic source area is indicated for this unit, presumably the underlying Eskasoni Formation and adjacent Shunacadie Pluton.

Mafic rocks interpreted to be thin basaltic flows (Hutchinson, 1952) or flows and dykes (Matthew, 1903) occur in the lower part of the Dugald Formation, above the quartz arenite unit, in Dugald and Gillis brooks. Their character is difficult to establish because they are strongly fractured and sheared, but on Gillis Brook, they appear to have chilled margins and are here interpreted to be sills.

\section{Gregwa Formation}

Hutchinson (1952) gave the name "Gregwa Formation" to a series of beds of "volcanic origin" that overlie the Dugald Formation, with the type section on Gregwa Brook (Fig. 2). As also reported by Matthew (1903) and Hutchinson (1952), the contact with the underlying Dugald Formation is generally sharp and conformable, but at some locations the two formations appear to be gradational. Locally the Dugald Formation is missing, and the Gregwa Formation occurs in faulted contact with the Eskasoni Formation (Figs. 2, 3). In the Bourinot Road area (Fig. 3), tuffaceous rocks of the Gregwa Formation are recognized in several outcrops.

The Gregwa Formation consists of orange to orange-brown and green siliceous lithic tuff, dark green to grey mafic(?) lithic tuff, minor dark grey to black tuffaceous siltstone, and rare light green and grey siltstone, rusty weathering shale, cream-coloured chert, and dark grey to grey-pink volcanogenic conglomerate. The lithic tuffs consist dominantly of fragments of spherulitic and flow-layered rhyolite and dacite, and minor amounts of andesitic to basaltic clasts. A distinctive feature of the tuffs is an abundance of glass shards and scoria fragments in the matrix. In some samples, feldspar and quartz crystals are also abundant in the matrix. No volcanic flows or fossils have been observed or reported in this formation.

\section{MacMullin Formation}

The MacMullin Formation (Hutchinson, 1952) is a sequence of shale and siltstone, with the type section in MacMullin Brook (Fig. 2). The formation is also well exposed along the valley of Indian River and in the lower parts of its tributaries. It extends northeastward to upper McLeod Brook where its thickness is greatly reduced (Fig. 3), perhaps as a result of faulting. Rocks that appear to be part of the MacMullin Formation are also well exposed in the northern part of the Bourinot belt, especially along the shore of St. Andrew Channel (Fig. 4). Based on his study of fossils collected in the latter area, Young (1913) assigned a late Middle Cambrian age to the MacMullin Formation. Hutchinson (1952) collected additional fossils from the same locality and suggested that the age is early Middle Cambrian.

The formation consists mainly of interbedded $(2-10 \mathrm{~cm})$ olive-green to green to grey, rarely dark grey to black, micaceous quartzitic siltstone, sandstone and shale. Locally thicker bedded sandstone ( $<100 \mathrm{~cm}$ thick) occurs interbedded with finegrained sandstone, siltstone and shale. The rocks exhibit a variety of sedimentary structures that include ripple-cross-laminations, ripples and slump structures. Trace fossils are numerous. A distinctive feature of the formation is the presence of thin ( $<5 \mathrm{~cm}$ wide), white to light grey, cross-stratified finegrained sandstone lenses. Associated with these layers are minor coarse-grained and pebbly sandstone lenses and beds (< $150 \mathrm{~cm}$ wide) with rare brachiopod(?) fragments. In addition to the above lithologies, the MacMullin Formation in the St. Andrew Channel area contains minor maroon shale and feldspathic sandstone and conglomerate. Another distinctive feature of the formation is the presence of light grey (rust-brown on weathered surfaces) calcareous lenses $(<200 \times 20 \mathrm{~cm})$ and disk-shaped nodules which appear to be more numerous toward the top of the formation. These lenses were not included in the original description of the formation by Hutchinson (1952).

The contact of the MacMullin Formation with the underlying Gregwa Formation in the Indian River area is sharp and conformable. It is best exposed above the waterfall on MacMullin Brook, where light grey silty shale and siltstone with minor calcareous lenses conformably overlie grey to green-grey lithic tuff containing fragments of porphyritic basalt and rhyolite. In the northeastern part of the belt, the contact with volcanic rocks to the east is interpreted to be a fault (Fig. 4), as first proposed by Young (1913).

\section{MacNeil Formation}

The MacNeil Formation (Hutchinson, 1952) is an Upper Cambrian black shale-dominated unit. The type section is exposed along MacNeil Brook, a tributary of the Mira River in southeastern Cape Breton Island (Fig. 1). In the Bourinot belt, rocks assigned to the MacNeil Formation are exposed in small patches along the southeastern margin of Indian Brook (Fig. 2), but the unit is best exposed along the valley of McLeod Brook and in small tributaries to the southeast (Fig. 3). We also found previously unreported outcrops of the MacNeil Formation along St. Andrew Channel (Fig. 4) but did not find rocks of the formation along the northwestern margin of McLeod Brook (Fig. 3 ), in contrast to Hutchinson $(1952$, p. 27).

The MacNeil Formation is generally a homogeneous sequence of dark grey to black shale, commonly containing rusty weathering nodules and lenses of black limestone that exhibit cone-in-cone structures. Rarely, lighter grey, silty, micaceous shale is present. These rocks typically contain tight folds and are commonly faulted and sheared.

The lower contact was not found exposed, but the abrupt change in depositional environment compared to the underlying MacMullin Formation may indicate that it is disconformable. Walcott (1912) and Hutchinson (1952) assigned a Late Cambrian age to the MacNeil Formation, based on their study of trilobites and brachiopods from the formation. 


\section{McLeod Brook Formation}

Hutchinson (1952) proposed the name "McLeod Brook Formation" for the shale-dominated unit that overlies the MacNeil Formation along the valley of McLeod Brook, where the type section was established. He suggested that these shales are truncated to the southwest near Bourinot Road by granitic intrusions, but these intrusions are now known to be Precambrian (Keppie et al., 1990; Barr et al., 1990), and hence truncation by faulting is more likely (Fig. 3).

The McLeod Brook Formation consists mainly of rustyweathering, light grey to black shale. On the basis of lithology, it is not readily distinguished from the MacNeil Formation; however, it lacks the abundant black limestone concretions characteristic of the latter formation. Black, siltstone beds $(<10 \mathrm{~cm}$ thick) are present locally, as well as pyrite nodules up to $3 \mathrm{~cm}$ in diameter.

An Early Ordovician age for the McLeod Brook Formation is based on the presence of trilobites, brachiopods and the graptolite Rhabdinopora flabelliforme (Matthew, 1903; Walcott, 1912; Hutchinson, 1952).

\section{Northern Boisdale Hills volcanic unit}

In the northern part of the Boisdale Hills, volcanic and minor associated sedimentary rocks on Long Island and in a fault-bounded wedge between the Mount Cameron syenogranite and sedimentary rocks of the MacMullin Formation (Fig. 4) are here termed informally the Northern Boisdale Hills volcanic unit. Both of these areas were previously assigned to the Bourinot Group by Hutchinson (1952), but that correlation is unlikely because of the new $\mathrm{U}-\mathrm{Pb}$ data presented below.

\section{Long Island}

On Long Island, the volcanic rocks are mainly rhyolitic flows and tuffs, with less abundant dacite and andesite. Basalt is present only in two small areas on the southwestern coast, and it is not clear if these represent flows or sills. The rhyolitic flows commonly display well developed eutaxitic banding. Flowaligned feldspar laths are characteristic of andesitic and dacitic rocks. Amygdales are common in many outcrops, in places forming streams both parallel and perpendicular to contacts. Coarse lapilli tuffs interlayered with flows are prominent on both the southern and northern tips of the island. Both sections young to the southeast and may be correlative, offset by complex faults in the central part of the island.

Around the northern tip of the island, fragments in the tuff are mainly varied types of rhyolite, with minor hornfels and basalt. The size of rhyolite fragments increases to the east, toward a spectacular coarse rhyolite breccia (B on Fig. 4) which is interpreted to be a vent facies. Several sills of massive rhyolite also occur in this section.

On the southern tip of the island, lapilli tuff occurs with conglomerate and minor laminated siltstone. The tuff contains rounded clasts of mainly dacitic composition and varied sizes up to $1 \mathrm{~m}$ diameter. It has been intruded by a nearly concordant sill about $1 \mathrm{~m}$ wide, of mafic composition, with well developed columnar jointing. A well layered conglomerate-sandstone-black siltstone unit appears to overlie the volcanic rocks on the east. Matthew (1903, p. 40) had reported that the clasts in conglomerate in this area are composed of grey, green and vesicular felsites similar to the adjacent volcanic rocks, an observation with which we concur. However, he also noted the presence of black flinty slate; we observed black cherty siltstone as layers in the sedimentary sequence, but no black slate as exotic clasts. In describing what we assume to be these same conglomerates, Helmstaedt and Tella (1972) reported the presence of "Long Island diorite", contact metamorphosed George River slate, and granite clasts of unknown provenance. None of these lithologies was observed in the present study. Diorite does not appear to be present on Long Island, so the nature of such clasts is particularly uncertain. Our petrographic examination of the volcanic clasts showed that they are mainly dacitic to andesitic volcanic fragments with a wide range of textures. Quartz grains with rounded (detrital) cores and diagenetic overgrowths are abundant. Also present are scoria and glass-shard-rich clasts and subhedral feldspar crystals. We interpret these conglomerates to be intraformational and mainly volcanogenic in origin.

Hutchinson (1952) had included these outcrops at the southern tip of Long Island in the MacMullin Formation and referred (p. 24) to the presence of fragmentary brachiopod shells. Matthew (1903, p. 40) also noted evidence of the ichnofossil Arenicolites. However, the outcrop locations are not clear and may refer to sections on the eastern coast of the island described below. The latest Cambrian to Early Ordovician radiometric data presented below for rhyolite from the west coast of the island strongly suggests that these rocks are not part of the Middle Cambrian MacMullin Formation. Additional evidence for this conclusion is the lack of abundant detrital muscovite in the associated siltstones, because elsewhere detrital muscovite is a characteristic component of the MacMullin Formation.

Hutchinson $(1952$, p. 9) reported that on the eastern shore of Long Island, thin beds of "green, tuffaceous shale and siltstone are interbedded with the volcanic rocks, and at one locality, fragments of brachiopod shells occur in those shales". Specific locations for these outcrops are not shown by Hutchinson (1952), and we could not find rocks that match his description. However, we observed sedimentary rocks in two areas on the eastern side of Long Island (Fig. 4). The northern area consists of siltstone and shale in faulted contact with the volcanic rocks. On the basis of lithology, in particular the abundance of muscovite, we include these rocks in the MacMullin Formation. The second area farther south (area C on Fig. 4) consists of sandstone and conglomerate, the latter containing rhyolitic clasts. These rocks are similar to conglomeratic layers at the southern and northern tips of the island and hence are interpreted to be part of the Northern Boisdale Hills volcanic unit. However, Matthew (1903, p. 40) apparently correlated these rocks, which occur in the area of the former ferry crossing between Long Island and the mainland, with the MacMullin Formation on the adjacent mainland.

\section{Mainland part of the unit}

The possibly correlative wedge of dominantly volcanic rocks on the mainland occurs between the MacMullin Formation and the Mount Cameron syenogranite in the northern Boisdale Hills 
(Fig. 4). It includes rhyolite, basalt and lapilli tuff, with minor conglomerate. The volcanic rocks in this area were previously included in the Middle Cambrian Bourinot Group and the overlying conglomerate in the Middle Cambrian MacMullin Formation. However, the conglomerate at locality A (Fig. 4), in addition to volcanic clasts, contains granophyric syenogranite clasts that appear to be from the Mount Cameron syenogranite, for which we report a latest Cambrian to earliest Ordovician age (see below), making correlation with the Bourinot Group unlikely if its Middle Cambrian age is correct. We therefore interpret these rocks to be in faulted contact with the Middle Cambrian MacMullin Formation. Abundant dacitic clasts in the conglomerate resemble dacitic flows on Long Island.

\section{Long Island metamorphic unit}

The metamorphic unit underlies about one third of Long Island (Fig. 4) and consists of metasiltstone (spotted hornfels), with marble, quartzite and calc-silicate layers. It also includes two distinctive types of dykes: (1) porphyry dykes composed of plagioclase phenocrysts in a quartz-biotite matrix, with abundant garnet xenocrysts and cordierite/biotite-rich metasedimentary xenoliths; and (2) at least one prominent andesitic dyke, about $25 \mathrm{~m}$ wide, that is folded with the host hornfels. The latter dyke has chilled margins but is quite coarse-grained in the centre. In places it is amygdaloidal with calcite and chlorite in the amygdales. These dyke rocks are shown as volcanic patches on the map of Bell and Goranson (1938), but are clearly intrusive and unlike any rocks in the Northern Boisdale Hills volcanic unit.

Locally, marble and calc-silicate layers in the unit contain the pseudofossil "Eozooon canadense" (confirmed by H.J. Hofmann, written communication, 1991).

The metamorphic unit on Long Island is similar to that exposed on the ridge northwest of McLeod Brook valley (Fig. 3). Both areas are assigned to the Benacadie Pond Formation (formerly part of the George River Group; Raeside and Barr, 1990). Hutchinson $(1952$, p. 9) suggested that, on Long Island, volcanic and sedimentary rocks of the Bourinot Group overlie these rocks with "slight angular discordance". However, strikes in the two units are almost at right angles (Fig. 4), and the northern contact is exposed as a major shear zone with strongly kinked metasedimentary rocks to the south and pulverised rhyolite on the north. Topographic trends suggest that the area of non-exposure between the two units at the southern contact also represents a fault.

Helmstaedt and Tella $(1972,1973)$ reported the presence of a limestone breccia with andesitic fragments in the upper parts of the "George River Group" on the western side of Long Island. They interpreted these fragments to have been derived from the Coxheath Hills belt of the Mira terrane (Fig. 1). We did not observe a limestone breccia, but even if it exists, see no justification for the specific correlation with volcanic rocks of the Coxheath Hills.

\section{U-PB DATA}

\section{Long Island rhyolite}

Rhyolite from the western coast of Long Island was sampled for dating (Fig. 4). The sample is a pink to brown, flow-layered rhyolite that consists of alternating light-coloured, microspherulitic layers ( $<2 \mathrm{~mm}$ wide) and darker-coloured, fine-grained porphyritic layers $(<10 \mathrm{~mm}$ wide). Phenocrysts are euhedral crystals of plagioclase, quartz and quartz aggregates, and scattered vesicles are also present. The sample contained pale yellow, euhedral prismatic zircon grains (length:breadth $=2: 1$ to 3:1). All of the zircons have excellent clarity, although many have reddish cloudy central zones parallel to the c-axis. Fractions C, E and F, composed of grains with reddish cloudy central cores, have significantly higher $U$ and $\mathrm{Pb}$ contents and higher ${ }^{206} \mathrm{~Pb} / 204 \mathrm{~Pb}$ and radiogenic ${ }^{208} \mathrm{~Pb}$ than those fractions without the reddish central zones (Table 1). However, the presence of the reddish central zones is not reflected in the analytical results (Fig. 5a). Four of the six fractions $\left(\mathrm{B}, \mathrm{C}, \mathrm{E}\right.$ and $\mathrm{F}$ ) yield similar ${ }^{207} \mathrm{~Pb} /{ }^{206} \mathrm{~Pb}$ ages in the range of 502 to $508 \mathrm{Ma}$. The other two fractions (A, D) give much older ${ }^{207} \mathrm{~Pb} / 206 \mathrm{~Pb}$ ages of $597 \pm 15 \mathrm{Ma}$ and $1698 \pm 10$ $\mathrm{Ma}$, respectively, as a result of inheritance (note that fraction D is not shown on the scale of Figure 5a). Fraction B is concordant, but imprecise due to low radiogenic $\mathrm{Pb}$ (Table 1). We consider the weighted ${ }^{207} \mathrm{~Pb} /{ }^{206} \mathrm{~Pb}$ age for fractions $\mathrm{B}, \mathrm{C}, \mathrm{E}$ and $\mathrm{F}$ of $505 \pm 3 \mathrm{Ma}$ to be the best estimate for the crystallization age for the sample, assuming that $\mathrm{Pb}$ loss was recent, a reasonable assumption given the lack of evidence for younger thermal events in Bras d'Or terrane.

\section{Mount Cameron syenogranite}

The Mount Cameron syenogranite forms the northern part of the Boisdale Hills Pluton of Barr and Setter (1986). It is pink to red and consists of scattered plagioclase and quartz microphenocrysts in a granophyric groundmass. No primary mafic mineral is present, but minor chlorite may have replaced biotite. A typical sample from the syenogranite was collected for dating from a quarry on the west margin of the pluton. Zircon grains from the sample are clear, euhedral, yellow, doubly terminated and prismatic. Most are 70 to 90 microns in length (length:breadth $=2: 1$ ). Data points 1 to 3 are concordant (Fig. $5 b)$ and give an average ${ }^{207} \mathrm{~Pb} / 206 \mathrm{~Pb}$ age of $509.3 \pm 1.4 \mathrm{Ma}(2$ sigma). The data point for fraction 4 plots slightly to the right of these points and gives an older ${ }^{207} \mathrm{~Pb} / 206 \mathrm{~Pb}$ age of 519.9 $\mathrm{Ma}$, perhaps due to a very small amount of inheritance in this multi-grain fraction. The ${ }^{207} \mathrm{~Pb} /{ }^{235} \mathrm{U}$ and ${ }^{206} \mathrm{~Pb} /{ }^{235} \mathrm{U}$ ages for this data point, however, are $509.1 \pm 1.4$ and $506.6 \pm 1.6$ $\mathrm{Ma}$, respectively, within error of the mean ${ }^{207} \mathrm{~Pb} /{ }^{206} \mathrm{~Pb}$ age for the rock. 
Table 1. U-Pb isotopic data for zircon from the Long Island rhyolite and the Mount Cameron syenogranite.

\begin{tabular}{|c|c|c|c|c|c|c|c|}
\hline Zircon fraction & $\begin{array}{l}\text { Weight } \\
\text { (mg) }\end{array}$ & $\begin{array}{c}\mathrm{U} \\
(\mathrm{ppm})\end{array}$ & $\begin{array}{r}\mathrm{Pb}^{*} \\
(\mathrm{ppm})\end{array}$ & $\begin{array}{c}208 \mathrm{~Pb} \\
(\%)\end{array}$ & $\begin{array}{c}\text { Measured } \\
206 \mathrm{~Pb} / 204 \mathrm{~Pb}\end{array}$ & $\begin{array}{c}\text { Isotopic Ratios } \\
206 \mathrm{~Pb} / 238 \mathrm{U} \quad 207 \mathrm{~Pb} / 235 \mathrm{U}\end{array}$ & $\begin{array}{c}\text { Age }(\mathrm{Ma}) \\
207 \mathrm{~Pb} / 206 \mathrm{~Pb}\end{array}$ \\
\hline
\end{tabular}

Long Island Rhyolite

\begin{tabular}{|c|c|c|c|c|c|c|c|c|}
\hline A. $\mathrm{N}+74-105$ & 0.016 & 167 & 15 & 18.3 & 466 & 0.08182 & 0.6749 & $597.1 \pm 14.7$ \\
\hline B. $N+149 S$ & 0.004 & 128 & 11 & 18.2 & 112 & 0.08083 & 0.6385 & $502.8 \pm 75.6$ \\
\hline C. $N+105 R$ & 0.013 & 2269 & 236 & 31.2 & 5214 & 0.07852 & 0.6201 & $502.2 \pm 2.0$ \\
\hline D. $M+105$ & 0.009 & 214 & 30 & 19.0 & 543 & 0.12093 & 1.7351 & $1698 \pm 9$ \\
\hline E. $N+74-149 R$ & 0.015 & 2633 & 279 & 31.7 & 5108 & 0.07939 & 0.6285 & $507.6 \pm 2.0$ \\
\hline F. $\mathrm{N}+74-149 \mathrm{R}$ & 0.010 & 2196 & 221 & 29.2 & 2469 & 0.07829 & 0.6198 & $507.7 \pm 3.4$ \\
\hline
\end{tabular}

Mount Cameron Syenogranite

$\begin{array}{lllllrlrl}\text { 1. M (60) } & 0.020 & 353 & 32 & 17.0 & 19575 & 0.08192 & 0.6493 & 510.2 \pm 3.4 \\ 2 . M(44) & 0.012 & 319 & 29 & 16.9 & 5401 & 0.08184 & 0.6487 & 510.2 \pm 2.2 \\ \text { 3. M (72) } & 0.025 & 386 & 35 & 17.2 & 18938 & 0.08229 & 0.6516 & 508.2 \pm 4.0 \\ \text { 4. M (90) } & 0.027 & 411 & 37 & 17.1 & 76608 & 0.08176 & 0.6509 & 519.9 \pm 2.8\end{array}$

* = radiogenic $\mathrm{Pb}$, blank corrected

Notes: $\mathrm{N}=$ non-magnetic at $<1^{\circ}$ side tilt, 1.7 amps on Frantz magnetic separator; $\mathrm{M}=$ magnetic at $>1^{\circ}, 1.7$ amps; numbers such as "+74-105" refer to size in microns; number of grains analyzed is given in brackets; $\mathrm{S}=$ single grain; $\mathrm{R}=$ grains with reddish, cloudy central zones. All zircon fractions were abraded to remove potentially altered outer parts of the grains (Krogh, 1982). Total procedural blanks for $\mathrm{Pb}$ and $\mathrm{U}$ are $15-25 \mathrm{pg}$ and $2 \mathrm{pg}$, respectively, for the Long Island rhyolite fractions and $1-4 \mathrm{pg}$ and $0.5 \mathrm{pg}$, respectively, for the Mount Cameron syenogranite. For the Long Island rhyolite, errors were propagated numerically (Roddick, 1987 ) and are quoted at the $2 \sigma$ level, with $207 \mathrm{~Pb} / 235 \mathrm{U}$ and $206 \mathrm{~Pb} / 238 \mathrm{U}$ errors averaging $0.98 \%$ and $0.60 \%$, respectively; analytical techniques are described in Parrish et al. (1987) and Bevier et al. (1993). For the Mount Cameron syenogranite, the measured ${ }^{206} \mathrm{~Pb} / 204 \mathrm{~Pb}$ ratio is corrected for spike fractionation and the $207 \mathrm{~Pb} / 235 \mathrm{U}$ and $206 \mathrm{~Pb} / 238 \mathrm{U}$ ratios are corrected for spike fractionation ( $0.10 \% / \mathrm{amu}$ for $\mathrm{Pb}$ and $\mathrm{U}$ ), blank $(2 \mathrm{pg} \mathrm{Pb}, 0.5 \mathrm{pg} \mathrm{U})$, and initial common $\mathrm{Pb}$ (Stacey and Kramers, 1975); all errors are $2 \sigma$ with those on both $\mathrm{Pb} / \mathrm{U}$ ratios ranging from 0.3 to $0.5 \%$, representing a minimum estimate of the analytical uncertainty for each analysis; further analytical details are described in Heaman and Machado (1992). All age determinations were calculated using the decay constants of Steiger and Jäger (1977).

\section{Implications of the $\mathrm{U}-\mathrm{Pb}$ ages}

The ages obtained from the Long Island rhyolite and Mount Cameron syenogranite overlap within error. However, given the $\mathrm{Pb}$ loss in the rhyolite zircon, it is likely that the rhyolite and syenogranite are the same age (ca. $509 \mathrm{Ma}$ ). This age approximately coincides within error with the Cambrian-Ordovician boundary as specified by Palmer (1983).

Based on the U-Pb date, the volcanic and interlayered sedimentary rocks on Long Island are similar in age to or slightly older than the Early Ordovician McLeod Brook Formation. However, uncertainty in the absolute age of the Cambrian-Ordovician boundary makes direct age comparison difficult. The McLeod Brook Formation is assumed to overlie the volcanic unit (Fig. 4).

The presence of volcanic and granophyric granitic clasts in conglomerate at locality A (Fig. 4) indicates that this conglomerate is not part of the Middle Cambrian MacMullin Formation, as previously assumed. As noted above, we propose that the conglomerate and adjacent volcanic rocks are correlative with the volcanic and conglomeratic rocks on Long Island, and together these rocks are termed informally the Northern Boisdale Hills volcanic unit.
The question arises as to whether or not the volcanic rocks of the Eskasoni Formation to the south in the Bourinot belt could also have an age of $c a$. $509 \mathrm{Ma}$. The Eskasoni Formation appears to be everywhere in faulted contact, both with Late Precambrian granitic and metamorphic rocks and with fossiliferous Middle Cambrian rocks of the Dugald Formation. The only direct evidence for age of the Eskasoni volcanic rocks is the unconfirmed interlayered fossiliferous shale noted above. However, the widespread close association between the Eskasoni and Dugald formations makes it unlikely that they have significantly different ages, even although their contact is faulted. Also, volcanic rocks in the Eskasoni Formation are mainly basalt with minor rhyolite, whereas the Northern Boisdale Hills volcanic unit consists of andesite, dacite and rhyolite with minor basalt, with abundant interlayered sedimentary rocks. Hence, the two units are not lithologically similar.

The $c a .509 \mathrm{Ma}$ age for the Mount Cameron syenogranite shows that it is not part of the Boisdale Hills Pluton, as previously assumed (Barr and Setter, 1986), because granodiorite of the Boisdale Hills Pluton has a minimum age of $c a .530 \mathrm{Ma}$, based on ${ }^{40} \mathrm{Ar} /{ }^{39} \mathrm{Ar}$ dating (Keppie et al., 1990), and petro- 

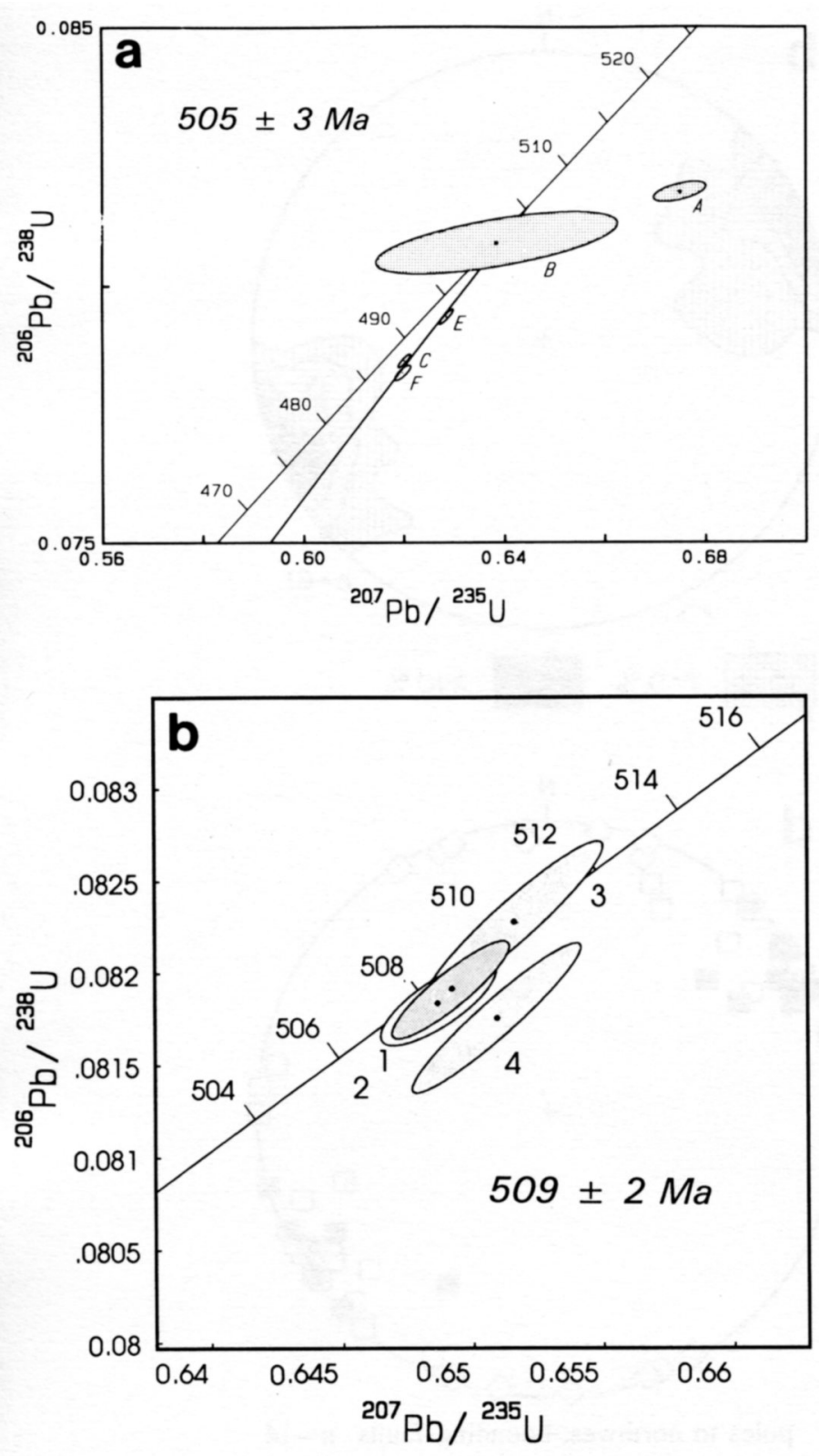

Fig. 5. Concordia plots for (a) Long Island rhyolite, and (b) Mount Cameron syenogranite. Data are from Table 1.

logical similarity to the $c a$. 560 Ma Shunacadie Pluton suggests that the crystallization age is ca. $560 \mathrm{Ma}$ (Barr and Setter, 1986; Barr et al., 1990).

\section{STRUCTURAL INTERPRETATION}

Previous studies in the Bourinot belt have not attempted to interpret the structure in detail, and the stratigraphic complexities introduced by the present study have not made structural interpretations any easier.

The Bourinot belt lies in a well-defined valley bounded by a system of northeast-trending, subvertical brittle faults, with flanking topographic highs. The orientation of meso- to macroscopic structures and the distribution of the stratigraphic formations in this belt indicate that the dominant structural feature is a northeast-trending, open to tight syncline $\left(F_{1}\right)$ (Figs. 6a, 7a-d). Associated with this phase of folding is an axial planar cleavage $\left(S_{1}\right)$ (Fig. $6 b$ ) that is best developed in the northeastern part of the belt and generally southwest-plunging minor folds, crenulation folds, and intersection lineations $\left(L_{1}\right)$ (Fig. 6c). Two major sets of faults are developed. The older faults are high-angle, northeast-trending (Figs. 1-4, 6d, 7a-d), and cut both limbs of the syncline. A later set of subparallel, subvertical, east-west-trending faults (Figs. 1-4, 6d) cuts all earlier structures.

In the Indian River area, rocks of the Eskasoni, Dugald, Gregwa, MacMullin, and locally the MacNeil formations are exposed. Volcanic layering and bedding $\left(\mathrm{S}_{0}\right)$ are generally overturned with tops to the southeast (Figs. 2, 7a). The southeastern limb of the syncline appears to have been completely faulted out. Minor fold axes plunge shallowly to the southwest with subvertical, northeast-trending axial planes that parallel a weakly developed cleavage. Upper and lower contacts of the Eskasoni Formation exhibit bedding-parallel faults.

In the upper part of McLeod Brook, the strata are folded into a broad, northeast-trending, open syncline (Figs. 3, 7b), whereas farther northeast, where the belt thins, stratigraphically higher units are exposed (Figs. 3, 7c). In the latter area, cleavage is moderately developed in the more shaly beds. Fold axis orientations are more varied but are generally the same as in the Indian River area. In contrast, Hutchinson (1952, p. 29) suggested that small-scale folds in this area are not related to the major structure.

In the northeastern part of the belt east of Long Island, the strata are folded into northwesterly overturned folds (Figs. 4, 7d), whereas farther northeast in the St. Andrews Channel area, folds are tight and upright. The folds that verge to the northwest do not conform to the overall wavetrain of the belt and are possibly related to an inferred fault in the strait between Long Island and the mainland (Fig. 4). Cleavage is moderately to well defined in this area and is axial planar to the upright folds. Bedding/cleavage intersections and minor fold axis orientations are subparallel. -

The Bourinot belt is flanked by northeast-trending, highangle faults. The faulted contact along the southeastern margin forms a discrete, steep scarp that mainly juxtaposes the Precambrian Boisdale Hills Pluton with the Bourinot belt. This contact was originally interpreted as intrusive (Hutchinson, 1952); however, Barr and Setter (1986) showed a faulted contact. The age of earliest faulting along this contact is unknown, although Helmstaedt and Tella $(1972,1973)$ suggested that faulting in this region was synchronous with folding. In the northwestern part of the belt (Fig. 4), an inlier of fossiliferous Windsor Group limestone adjacent to the fault scarp contains subrounded granitic clasts from the Mount Cameron syenogranite. This indicates that the pluton was a topographic high at the time of Windsor Group deposition. Other than Carboniferous rocks, no other horizon can be traced across the fault and so no direct estimates on the amount of movement can be made. Measured slickenside orientations show considerable scatter.

The contact along the northwestern margin of the belt is a complexly anastomosing fault zone that juxtaposes Precambrian igneous and metamorphic rocks with the Bourinot belt (Fig. 1). This contact was originally defined as an unconformity by Hutchinson (1952) and Helmstaedt and Tella (1972, 1973). 

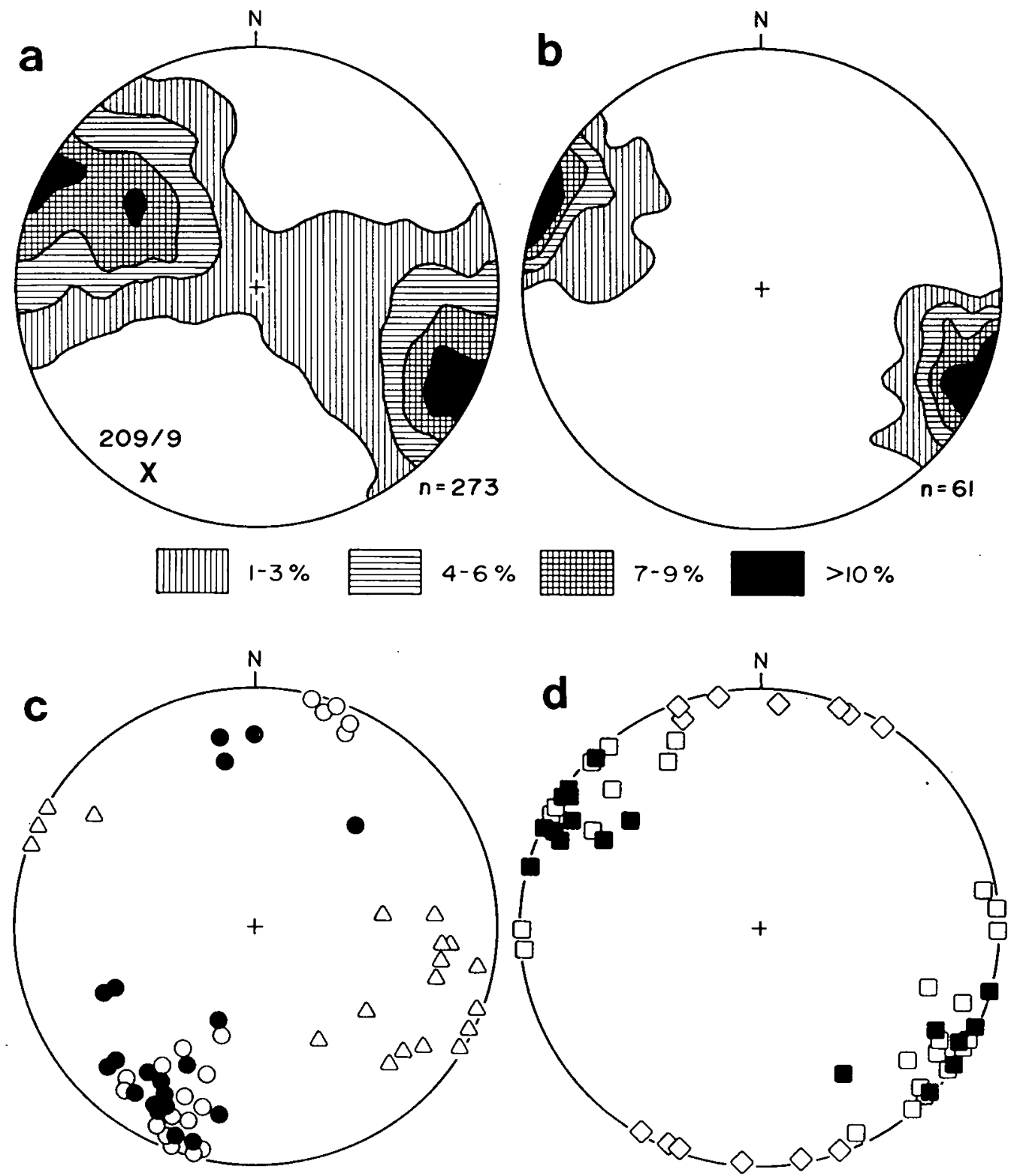

- fold axes $n=22$
$\triangle$ intersection lineation $n=22$
$\triangle$ poles to axial planes $n=16$

poles to northwest-bounding faults $n=14$

poles to southeast-bounding faults $n=2$ l

$\diamond$ poles to east-west-trending faults $n=8$

Fig. 6. Structural data plotted on stereonets: (a) poles to bedding, $X=$ regional fold axis; (b) poles to cleavage; (c) measurements of fold axes, intersections lineations, and poles to axial planes; (d) poles to fault planes.

Hutchinson (1952, p. 8-9) suggested that Eskasoni, Dugald and Gregwa formations wedge out to the northeast as a result of facies changes. Our mapping shows that this "facies change" is related to the anastomosing character of this fault zone. In the northeast this fault zone appears to be overlain by conglomerate of the Carboniferous Horton Group, suggesting pre-Carboniferous movement. However, not all movement on these northeast-trending faults was pre-Carboniferous. At Youngs Point, northeast of Long Island, sedimentary rocks of the Carboniferous Windsor Group appear to be faulted against the MacMullin Formation.

In the Bourinot belt, contacts among the more resistant stratigraphic units such as the Eskasoni Formation are beddingparallel faults which gives rise to a stairstep-like topography.
Based on field observations and topographic lineaments, numerous major and minor, east-west-trending, subvertical, faults (Figs. 1-4, 7d) truncate all structures and offset the northeast-trending fault systems. Amount of movement along these faults is uncertain but is considered to have been minimal.

\section{Petrochemistry and tectonic Setting OF IGNEOUS UNITS}

Helmstaedt and Tella (1973) suggested that the Middle Cambrian volcanic rocks in the Bourinot belt were formed in a compressional orogenic tectonic environment. However, subsequent geochemical studies (e.g., Cameron, 1980; Keppie and 

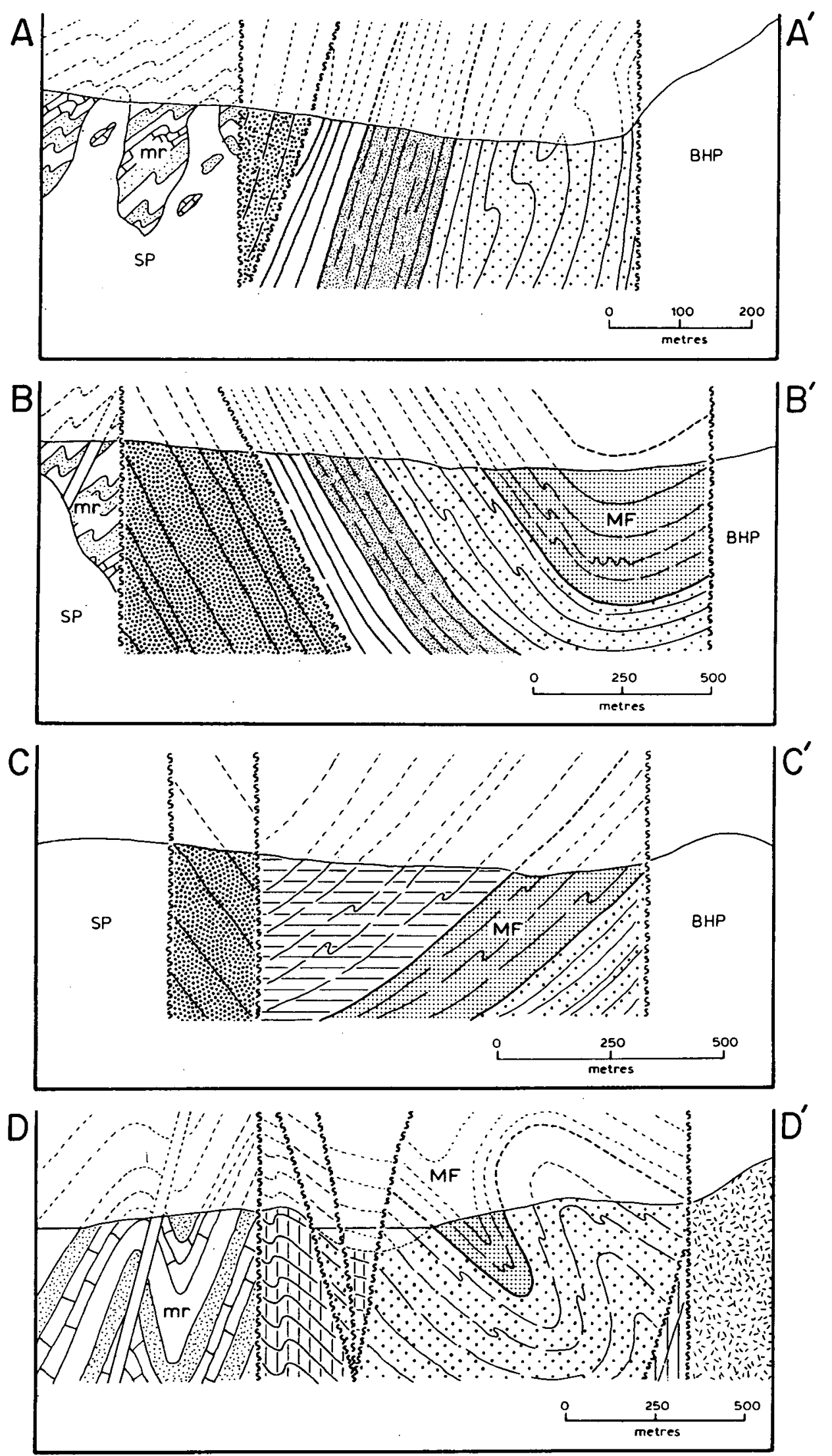

Fig. 7. Cross-sections A-A', B-B', C-C', and D-D' from south to north across the Bourinot belt. Locations are shown on Figures 2, 3 and 4 . Unit symbols are as in Figures 2, 3 and 4. 
Dostal, 1980; Murphy et al., 1985) generally indicated that the volcanic rocks formed in a continental rift setting. Here, new petrochemical data from volcanic rocks of the Eskasoni Formation, possible mafic sills in the Dugald Formation, volcanic rocks of the Northern Boisdale Hills volcanic unit, and the Mount Cameron syenogranite are used in combination with previously published analyses from the volcanic units in an attempt to better resolve the tectonic setting in which the rocks formed.

Basalt of the Eskasoni Formation typically contains plagioclase phenocrysts in an intersertal to intergranular groundmass of flow-aligned plagioclase laths, interstitial clinopyroxene and $\mathrm{Fe}-\mathrm{Ti}$ oxides. Some samples contain altered phenocrysts of olivine, pseudomorphed by chlorite, carbonate and hematite. Chlorite and hematite are also abundant in the groundmass, and in many samples, no clinopyroxene is preserved. Samples from the mafic units interpreted to be sills near the base of the Dugald Formation are petrographically similar to the basalts, but are aphyric, show stronger flow-alignment of plagioclase laths, and subophitic rather than intergranular texture.

Rhyolite in the Eskasoni Formation typically has eutaxitic, spherulitic and patchy devitrification textures. Sparse microphenocrysts of quartz and feldspar are generally present. Lithic tuffs consist mainly of pink to red angular fragments of eutaxitic, phenocrystic and spherulitic rhyolite, with less abundant fragments of basalt/andesite with trachytic textures, and euhedral to subhedral quartz and feldspar crystals $(<1 \mathrm{~mm}$ in size) in a cryptocrystalline groundmass.

Analyzed samples from the Eskasoni Formation (Table 2; Cameron, 1980; Murphy et al., 1985) reflect the bimodal composition of the unit; basaltic samples have silica contents averaging about $49 \%$, whereas felsic samples range from about 65 to $73 \% \mathrm{SiO}_{2}$ (Fig. 8). Relatively high and variable loss-on-ignition values are consistent with the degree of alteration apparent in hand specimen and thin section. Both mafic and felsic samples are dominantly subalkaline (Fig. 8). On discrimination diagrams, the mafic samples plot mainly in the withinplate basalt fields, although with overlap in MORB and VAB fields (Fig. 9a, b). Some samples reported by Murphy et al. (1985) (originally from Cameron, 1980) show a spread to relatively high $Y$ values that has no obvious petrogenetic significance and may be a result of analytical error in $\mathrm{Y}$ data. Felsic samples also plot mainly in the within-plate field (Fig. 10).

The two samples from the sills(?) in the Dugald Formation are chemically similar to the basalts from the underlying Eskasoni Formation (Table 2; Figs. 8, 10), suggesting that sporadic mafic magmatism of similar type persisted after eruption of the Eskasoni volcanic sequence.

Clinopyroxene composition provides an additional indication of magma type and tectonic setting for basaltic rocks (Leterrier et al., 1982) that may be more reliable than wholerock geochemistry in altered suites such as this one. However, the pyroxene data of Murphy et al. (1985), as well as the data for pyroxene from the Dugald Formation sills, span the alkalic/ non-alkalic boundary line (Fig. 11a). If the rocks are assumed to be non-alkalic, then the $\mathrm{Ti}, \mathrm{Cr}$ and $\mathrm{Ca}$ contents indicate a non-orogenic (within-plate) setting (Fig. 11b), consistent with the whole-rock chemistry.

In comparison with the Eskasoni Formation, the volcanic rocks in the Northern Boisdale Hills volcanic unit are not bi- modal. They are mainly andesitic, but dacite, rhyolite and basalt are also present. Dacitic and rhyolitic samples are spherulitic, with scattered plagioclase and sanidine phenocrysts and abundant amygdales, and generally well developed layering due to flow. The andesitic samples are characterized by aligned plagioclase laths and sparse plagioclase microphenocrysts. Rare basaltic flows (or possibly dykes) have intergranular textures. Overall, the character of the rocks suggest that they formed as subaerial flows.

The analyzed samples from the unit on Long Island display a continuum in composition from mafic to felsic (Fig. 8). The single analyzed mafic sample is compositionally similar to the basaltic samples from the Eskasoni and Dugald formations, and a tholeiitic affinity and within-plate setting is indicated, both from whole-rock geochemistry (Fig. 9a, b) and clinopyroxene composition (Fig. 11a, b). The felsic samples are more equivocal in terms of tectonic setting (Fig. 10), and the limited number of such samples does not permit a firm conclusion.

The Mount Cameron syenogranite is more siliceous than the analyzed volcanic samples from Long Island, but rhyolite samples from the wedge of volcanic rocks west of the syenogranite are similarly high in $\mathrm{SiO}_{2}$ (Fig. 8), although they differ from the Mount Cameron samples by having higher $\mathrm{Zr} /$ $\mathrm{TiO}_{2}$ and by plotting in the within-plate field (Fig. 10). Hence, it is not clear from the chemical data that the syenogranite and the associated extrusive rocks, apparently of similar age, are co-genetic. More detailed petrochemical study is needed to resolve this question.

\section{DisCUSSION AND IMPLICATIONS}

If both the previously reported fossil evidence and the U$\mathrm{Pb}$ dates presented here are correct, they show a complex stratigraphic and structural configuration, as shown in the crosssections in Figure 7.

Contact metamorphic hornfels reported by Helmstaedt and Tella (1972) in Cambrian or Ordovician rocks in the Barachois Harbour area (Fig. 4) were interpreted to confirm the occurrence of younger plutons in the area. However, the only contact metamorphic rocks observed in that area during the present study are of Precambrian age. Because the adjacent plutonic rocks are now known to be Precambrian (Barr et al., 1990), the presence of hornfels in these Cambrian-Ordovician units is unlikely, except possibly adjacent to the Mount Cameron syenogranite.

Although other volcanic rocks of possible Late Cambrian to Early Ordovician age are not known in Cape Breton Island, plutons of similar age appear to be widespread in the Bras d'Or terrane. They include, in addition to the Mount Cameron syenogranite, the Kellys Mountain and Cape Smoky granites, dated by U-Pb (zircon) at $495 \mathrm{Ma}$ and $493 \mathrm{Ma}$, respectively (Dunning et al., 1990; Barr et al., 1990), and possibly the Creignish and West Bay granites (Raeside and Barr, 1990).

Raeside and Barr (1990) suggested that the Bras d'Or terrane may not have been in close proximity to Mira terrane during the Cambrian and early Ordovician and that the Bourinot belt was derived tectonically from the Mira terrane. However, the results of the present study do not support an allocthonous relationship between the Bourinot belt and adjacent Bras d'Or 
Table 2. Whole-rock chemical analyses* of samples from volcanic rocks of the Bourinot Belt and the Mount Cameron syenogranite.

\begin{tabular}{|c|c|c|c|c|c|c|c|c|c|c|c|c|c|c|c|c|c|}
\hline Sample & 1 & 2 & 3 & 4 & 5 & 6 & 7 & 8 & 9 & 10 & 11 & 12 & 13 & 14 & 15 & 16 & 17 \\
\hline \multicolumn{18}{|c|}{ Major elements (wt. \%) } \\
\hline $\mathrm{SiO}_{2}$ & 46.15 & 73.24 & 64.24 & 65.03 & 66.38 & 72.90 & 48.42 & 44.77 & 48.26 & 47.55 & 40.63 & 60.51 & 61.81 & 51.62 & 71.53 & 72.50 & 56.67 \\
\hline $\mathrm{TiO}_{2}$ & 1.43 & 0.47 & 0.77 & 0.79 & 0.41 & 0.10 & 2.22 & 1.70 & 2.38 & 3.72 & 2.33 & 1.09 & 1.10 & 1.36 & 0.27 & 0.28 & 1.03 \\
\hline $\mathrm{Al}_{2} \mathrm{O}_{3}$ & 18.14 & 14.60 & 17.31 & 18.34 & 16.76 & 13.84 & 16.81 & 17.47 & 18.17 & 14.37 & 15.88 & 16.09 & 16.68 & 17.13 & 13.90 & 13.88 & 16.56 \\
\hline $\mathrm{Fe}_{2} \mathrm{O}_{3} \mathrm{~T}$ & 9.75 & 2.01 & 4.90 & 4.49 & 3.70 & 1.22 & 12.00 & 10.72 & 9.71 & 14.90 & 12.78 & 7.36 & 6.29 & 9.63 & 2.62 & 2.11 & 7.38 \\
\hline $\mathrm{MnO}$ & 0.29 & 0.03 & 0.13 & 0.09 & 0.03 & 0.01 & 0.20 & 0.22 & 0.32 & 0.26 & 0.27 & 0.11 & 0.14 & 0.16 & 0.01 & 0.01 & 0.18 \\
\hline $\mathrm{MgO}$ & 7.73 & 0.39 & 1.49 & 1.38 & 1.17 & 0.04 & 7.12 & 7.32 & 7.66 & 5.45 & 3.51 & 1.43 & 1.74 & 5.82 & 0.30 & 0.37 & 4.56 \\
\hline $\mathrm{CaO}$ & 3.78 & 1.10 & 1.36 & 0.46 & 0.51 & 0.00 & 4.53 & 6.64 & 3.75 & 5.19 & 8.44 & 0.96 & 1.37 & 4.69 & 0.05 & 0.31 & 2.97 \\
\hline $\mathrm{Na}_{2} \mathrm{O}$ & 4.90 & 3.32 & 5.95 & 5.56 & 2.33 & 0.87 & 4.55 & 3.42 & 4.84 & 5.18 & 5.40 & 7.69 & 7.11 & 4.99 & 0.25 & 0.26 & 4.82 \\
\hline $\mathrm{K}_{2} \mathrm{O}$ & 0.30 & 2.70 & 1.92 & 2.65 & 3.89 & 9.42 & 0.86 & 0.37 & 0.08 & 0.46 & 0.79 & 2.44 & 2.12 & 1.50 & 10.17 & 9.21 & 0.81 \\
\hline $\mathrm{P}_{2} \mathrm{O}_{5}$ & 0.22 & 0.08 & 0.19 & 0.19 & 0.02 & 0.01 & 0.30 & 0.23 & 0.33 & 0.50 & 0.30 & 0.42 & 0.44 & 0.20 & 0.05 & 0.06 & 0.18 \\
\hline LOI & 7.90 & 2.60 & 2.80 & 2.20 & 3.30 & 1.00 & 3.90 & 7.00 & 4.50 & 3.20 & 9.40 & 1.60 & 2.00 & 3.60 & 1.20 & 1.60 & 5.20 \\
\hline TOTAL & 100.59 & 100.54 & 101.06 & 101.18 & 98.50 & 99.41 & 100.91 & 99.86 & 100.00 & 100.78 & 99.73 & 99.70 & 100.80 & 100.70 & 100.35 & 100.59 & 100.36 \\
\hline
\end{tabular}

Trace elements (ppm)

\begin{tabular}{|c|c|c|c|c|c|c|c|c|c|c|c|c|c|c|c|c|c|}
\hline $\mathrm{Ba}$ & 102 & 64 & 241 & 351 & 431 & 1313 & 591 & 216 & 95 & 460 & 104 & 399 & 385 & 257 & 1395 & 1888 & 233 \\
\hline $\mathrm{Rb}$ & 6 & 87 & 92 & 153 & 222 & 211 & 30 & 8 & 5 & 10 & 28 & 74 & 56 & 45 & 305 & 313 & 20 \\
\hline $\mathrm{Sr}$ & 436 & 60 & 123 & 156 & 94 & 30 & 322 & 380 & 366 & 393 & 100 & 391 & 296 & 340 & 27 & 57 & 254 \\
\hline$Y$ & 29 & 51 & 67 & 60 & 73 & 51 & 38 & 31 & 37 & 49 & 41 & 55 & 61 & 24 & 43 & 50 & 25 \\
\hline $\mathrm{Zr}$ & 143 & 421 & 417 & 408 & 500 & 337 & 177 & 153 & 176 & 266 & 174 & 337 & 348 & 117 & 355 & 359 & 160 \\
\hline $\mathrm{Nb}$ & 5 & 14 & 16 & 14 & 17 & 11 & 5 & 8 & 5 & 6 & 10 & 14 & 10 & 5 & 12 & 11 & 5 \\
\hline Th & 10 & 10 & 10 & 10 & 11 & 14 & 10 & 10 & 10 & 10 & 10 & 10 & 10 & 10 & 11 & 10 & 10 \\
\hline $\mathrm{Pb}$ & 10 & 10 & 21 & 16 & 10 & 10 & 10 & 1 & 10 & 10 & 10 & 10 & 11 & 10 & 10 & 10 & 10 \\
\hline $\mathrm{Ga}$ & 17 & 14 & 23 & 26 & 20 & 12 & 16 & 21 & 21 & 20 & 20 & 21 & 19 & 19 & 12 & 18 & 14 \\
\hline $\mathrm{Zn}$ & 80 & 37 & 119 & 96 & 72 & 22 & 102 & 101 & 137 & 129 & 113 & 82 & 90 & 170 & 45 & 45 & 72 \\
\hline $\mathrm{Cu}$ & 9 & 15 & 5 & 5 & 39 & 5 & 16 & 29 & 51 & 33 & 8 & 5 & 5 & 17 & 8 & 7 & 8 \\
\hline $\mathrm{Ni}$ & 128 & 5 & 5 & 5 & 5 & 5 & 63 & 71 & 73 & 23 & 6 & 5 & 5 & 49 & 5 & 5 & 39 \\
\hline V & 242 & 5 & 10 & 13 & 5 & 5 & 334 & 266 & 317 & 424 & 431 & 37 & 32 & 219 & 8 & 5 & 195 \\
\hline $\mathrm{Cr}$ & 239 & 5 & 5 & 5 & 5 & 5 & 172 & 203 & 169 & 8 & 15 & 5 & 5 & 79 & 5 & 5 & 97 \\
\hline
\end{tabular}

*Analyzed sample locations are shown on Figures 2, 3 and 4. Analyses were done using X-ray fluorescence at the Regional Geochemical Centre, Saint Mary's University, Halifax. LOI is loss-on-ignition; $\mathrm{Fe}_{2} \mathrm{O}_{3} \mathrm{~T}$ is total iron expressed as $\mathrm{Fe}_{2} \mathrm{O}_{3}$; nd = not determined. Samples 1 to 8 are basalts and rhyolites from the Eskasoni Formation, samples 9 and 10 are from mafic sills in the Dugald Formation, samples 11 to 25 are from the Northern Boisdale Hills volcanic unit, and samples 26 to 33 are from the Mount Cameron syenogranite. 
Table 2 Continued.

\begin{tabular}{|c|c|c|c|c|c|c|c|c|c|c|c|c|c|c|c|c|}
\hline Sample & 18 & 19 & 20 & 21 & 22 & 23 & 24 & 25 & 26 & 27 & 28 & 29 & 30 & 31 & 32 & 33 \\
\hline \multicolumn{17}{|c|}{ Major elements (wt. \%) } \\
\hline $\mathrm{SiO}_{2}$ & 68.44 & 57.42 & 60.17 & 68.68 & 71.29 & 69.83 & 76.13 & 49.67 & 74.20 & 74.46 & 75.48 & 76.30 & 77.50 & 75.12 & 78.00 & 76.70 \\
\hline $\mathrm{TiO}_{2}$ & 0.22 & 1.43 & 1.51 & 0.69 & 0.21 & 0.41 & 0.17 & 2.42 & 0.25 & 0.23 & 0.17 & 0.15 & 0.15 & 0.14 & 0.12 & 0.14 \\
\hline $\mathrm{Al}_{2} \mathrm{O}_{3}$ & 14.08 & 16.31 & 15.09 & 14.81 & 14.26 & 12.66 & 11.79 & 16.71 & 13.80 & 13.14 & 12.99 & 13.90 & 12.70 & 12.99 & 12.80 & 12.50 \\
\hline $\mathrm{Fe}_{2} \mathrm{O}_{3} \mathrm{~T}$ & 3.79 & 7.70 & 7.67 & 3.56 & 1.06 & 2.23 & 2.02 & 11.86 & 1.34 & 1.44 & 0.99 & 1.05 & 0.80 & 0.99 & 0.91 & 1.22 \\
\hline $\mathrm{MnO}$ & 0.05 & 0.11 & 0.17 & 0.07 & nd & 0.06 & 0.03 & 0.23 & 0.03 & 0.03 & 0.03 & 0.04 & 0.04 & 0.03 & 0.04 & 0.04 \\
\hline $\mathrm{MgO}$ & 0.26 & 1.27 & 1.31 & 0.82 & 0.09 & 0.18 & 0.20 & 5.69 & 0.23 & 0.20 & 0.10 & 0.26 & 0.20 & 0.06 & 0.14 & 0.23 \\
\hline $\mathrm{CaO}$ & 0.08 & 2.82 & 1.57 & 0.94 & 0.03 & 1.81 & 0.14 & 3.87 & 0.31 & 0.90 & 1.10 & 0.84 & 0.57 & 0.47 & 0.50 & 0.73 \\
\hline $\mathrm{Na}_{2} \mathrm{O}$ & 0.13 & 4.53 & 4.50 & 3.84 & 0.16 & 1.53 & 3.24 & 5.48 & 4.50 & 4.66 & 3.98 & 4.20 & 3.90 & 4.00 & 4.10 & 4.50 \\
\hline $\mathrm{K}_{2} \mathrm{O}$ & 10.06 & 3.94 & 2.28 & 5.08 & 9.58 & 7.11 & 4.02 & 0.63 & 4.60 & 3.12 & 3.72 & 3.60 & 4.30 & 4.30 & 3.40 & 3.40 \\
\hline $\mathrm{P}_{2} \mathrm{O}_{5}$ & 0.03 & 0.50 & 0.46 & 0.17 & 0.03 & 0.09 & 0.03 & 0.36 & 0.03 & 0.04 & 0.03 & 0.03 & 0.03 & 0.03 & 0.01 & 0.01 \\
\hline LOI & 2.70 & 4.10 & 6.50 & 1.80 & 1.70 & 3.70 & 0.50 & 4.20 & 0.60 & 0.80 & 0.40 & 0.20 & 0.40 & 0.50 & 0.10 & 0.20 \\
\hline TOTAL & 99.84 & 100.13 & 101.23 & 100.46 & 98.41 & 99.61 & 98.27 & 101.12 & 99.89 & 99.02 & 98.99 & 100.57 & 100.59 & 98.63 & 100.12 & 99.67 \\
\hline \multicolumn{17}{|c|}{ Trace elements (ppm) } \\
\hline $\mathrm{Ba}$ & 690 & 682 & 228 & 850 & 824 & 610 & 452 & 189 & 405 & 362 & 401 & 407 & 372 & 360 & 365 & 348 \\
\hline $\mathrm{Rb}$ & 354 & 121 & 66 & 156 & 331 & 219 & 141 & 20 & 121 & 87 & 119 & 102 & 170 & 162 & 125 & 96 \\
\hline $\mathrm{Sr}$ & 27 & 86 & 45 & 114 & 35 & 35 & 63 & 293 & 36 & 108 & 142 & 91 & 48 & 50 & 76 & 69 \\
\hline$Y$ & 59 & 53 & 36 & 34 & 39 & 31 & 110 & 37 & 34 & 27 & 21 & 24 & 22 & 37 & 38 & 29 \\
\hline $\mathrm{Zr}$ & 291 & 234 & 217 & 298 & 278 & 225 & 792 & 178 & 191 & 185 & 137 & 135 & 118 & 174 & 175 & 169 \\
\hline $\mathrm{Nb}$ & 12 & 9 & 7 & 14 & 11 & 12 & 31 & 5 & 11 & 10 & 8 & 10 & 10 & 15 & 13 & 14 \\
\hline Th & 12 & 10 & 10 & 10 & 13 & 12 & 17 & 10 & 14 & 14 & 17 & 12 & 10 & 17 & 10 & 13 \\
\hline $\mathrm{Pb}$ & 10 & 10 & 10 & 10 & 10 & 10 & 10 & 10 & 10 & 10 & 10 & 10 & 10 & 10 & 10 & 10 \\
\hline $\mathrm{Ga}$ & 18 & 22 & 16 & 14 & 16 & 15 & 26 & 18 & 13 & 13 & 13 & 13 & 12 & 17 & 17 & 13 \\
\hline $\mathrm{Zn}$ & 31 & 97 & 66 & 50 & 11 & 18 & 71 & 133 & 31 & 29 & 12 & 25 & 30 & 18 & 35 & 21 \\
\hline $\mathrm{Cu}$ & 5 & 5 & 5 & 5 & 5 & 5 & 5 & 25 & 5 & 5 & 5 & 5 & 5 & 5 & 5 & 5 \\
\hline $\mathrm{Ni}$ & 5 & 5 & 5 & 5 & 5 & 5 & 5 & 67 & 8 & 5 & 5 & 8 & 8 & 5 & 6 & 5 \\
\hline V & 7 & 99 & 94 & 29 & 5 & 29 & 6 & 390 & 5 & 8 & 5 & 5 & 5 & 5 & 5 & 5 \\
\hline $\mathrm{Cr}$ & 5 & 5 & 5 & 5 & 5 & 5 & 6 & 121 & 30 & 10 & 7 & 42 & 41 & 6 & 37 & 48 \\
\hline
\end{tabular}




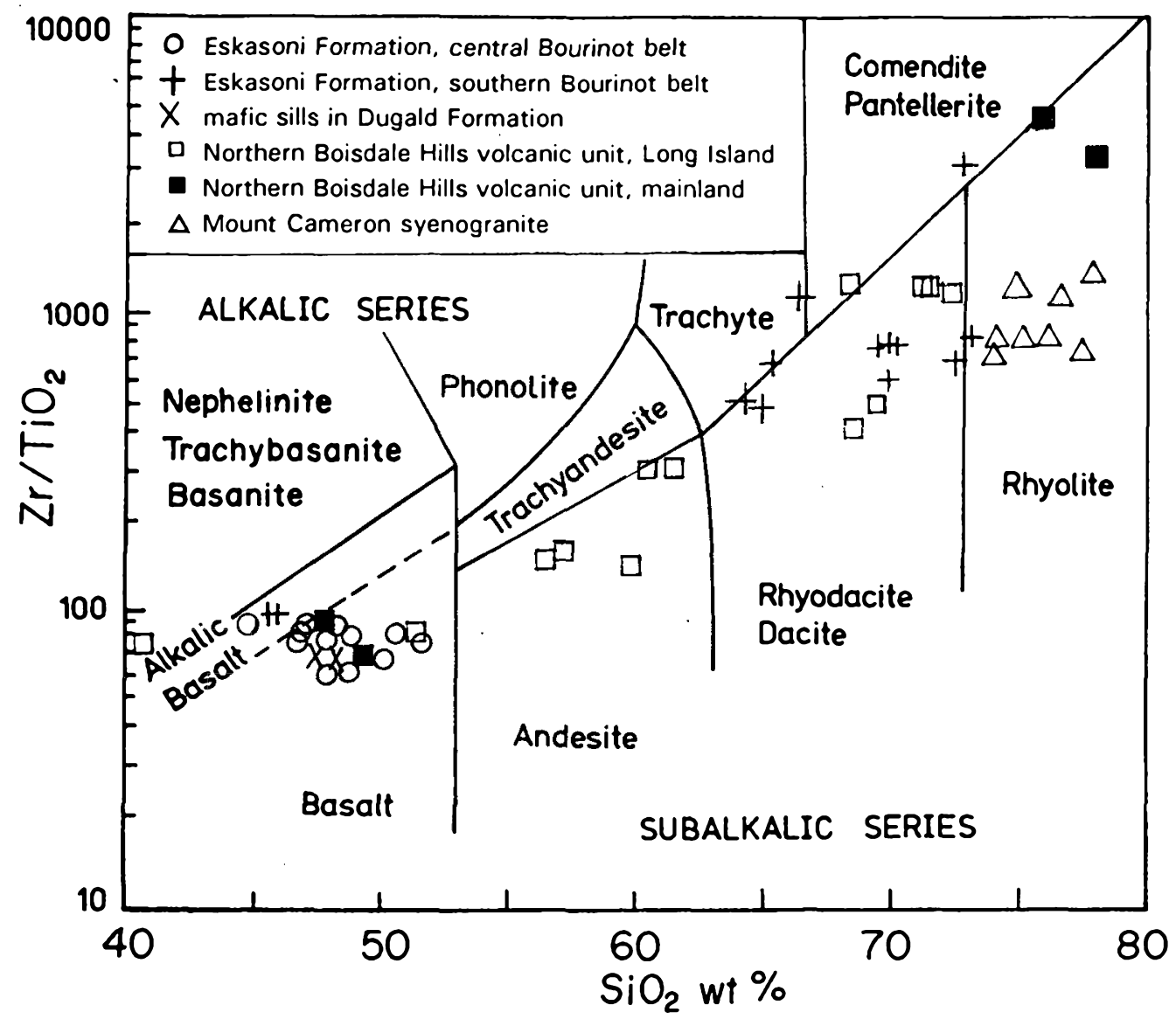

Fig. 8. Plot of $\mathrm{Zr} / \mathrm{TiO}_{2}$ against $\mathrm{SiO}_{2}$, with fields from Winchester and Floyd (1977). Data are from Table 2 and Murphy et al. (1985).
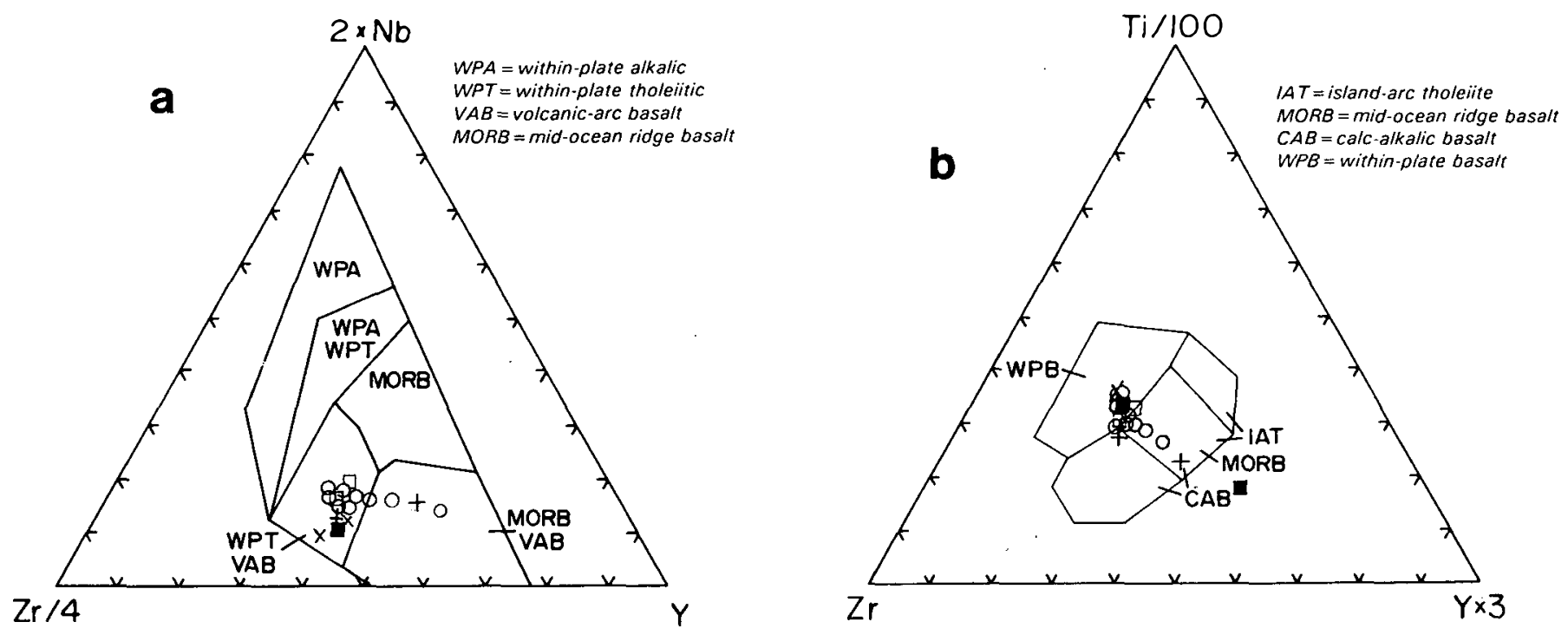

Fig. 9. (a) Nb-Zr-Y ternary diagram for mafic samples, with fields from Meschede (1986). (b) Ti-Y-Zr ternary diagram for mafic samples, with fields from Pearce and Cann (1973). Symbols as in Figure 8.

terrane units, although contacts are faulted. Nevertheless, it should be pointed out that Cambrian and Ordovician stratigraphic units in the two areas are not as similar as commonly implied, with the exception of the Upper Cambrian MacNeil Formation. Differences include the absence of Lower Cambrian units in the Bourinot belt and the absence of Cambrian volca- nic rocks and Ordovician rocks in the Mira area. The idea that Middle Cambrian volcanic rocks occur in the Mira River area has been generally accepted in the past, in part because of confusion about the age of the Stirling belt and its inclusion in the Cambrian by Weeks (1954), as well as the subsequent work of Smith (1978). However, our recent studies have demonstrated 


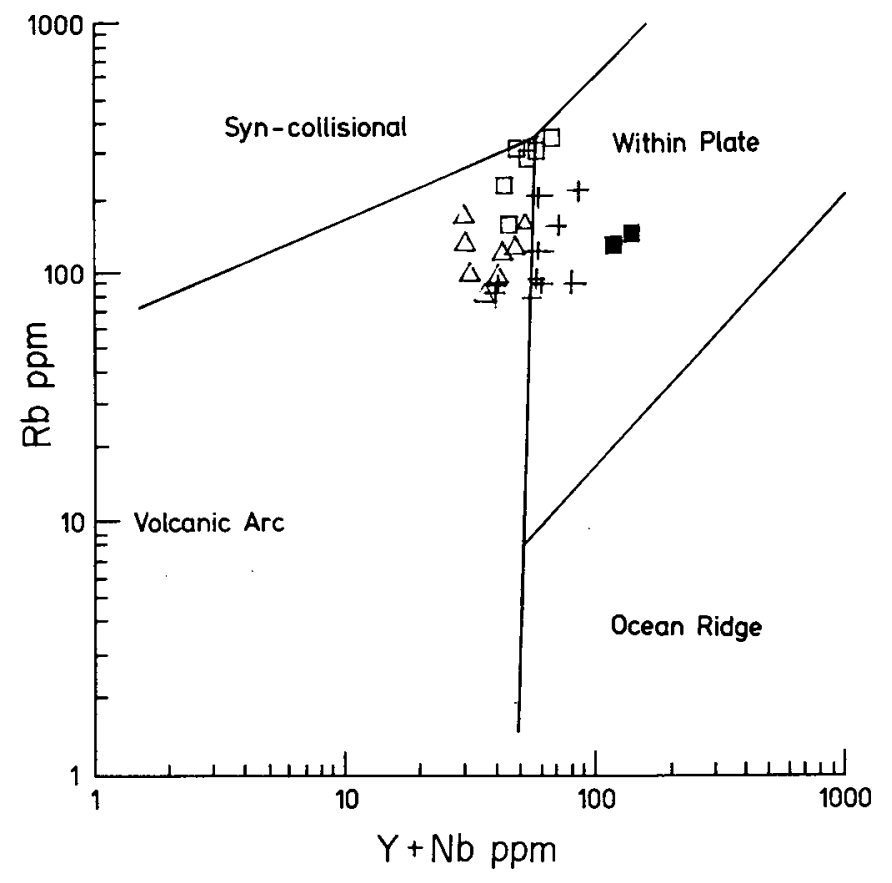

Fig. 10. Plot of $\mathrm{Rb}$ against $\mathrm{Y}+\mathrm{Nb}$ for felsic samples, with fields from Pearce et al. (1984). Symbols as in Figure 8.

that there are no Cambrian or Ordovician volcanic or plutonic rocks in Mira River area (Barr et al., 1992).

Middle Cambrian volcanic rocks has been documented in the Avalon terrane of eastern Newfoundland (Greenough and Papezik, 1985), in the Antigonish Highlands (Murphy et al., 1985), and in southern New Brunswick (Greenough et al., 1985). However, the most likely correlatives of the Bourinot belt may be volcanic and sedimentary rocks in the New River belt in southern New Brunswick, where recent work has documented the presence of rhyolite with an age of $c a .515 \mathrm{Ma}$ (Johnson et al., 1993; Johnson and McLeod, 1994).

Petrochemical features of $c a$. $560 \mathrm{Ma}$ plutons such as Shunacadie and Boisdale Hills plutons indicate that they may have formed in a subduction-related setting at a convergent continental margin (Raeside and Barr, 1990). At places in the Bras d'Or terrane, high-grade metamorphism has been documented at ca. $540 \mathrm{Ma}$. However, by early Middle Cambrian time, the Bourinot belt basin was developing, possibly as a post-orogenic rift. Bimodal volcanism represented by the Eskasoni Formation occurred in the early stages of basin development, with associated and overlying clastic sediments (Dugald Formation) derived from adjacent granitoid and metamorphic sources, as well as the volcanic terrain. Minor felsic volcanism continued during deposition of the Gregwa Formation but waned during the time the MacMullin, McNeil and McLeod Brook formations were formed in the Middle and Late Cambrian and Early Ordovician, possibly in a deepening marine basin. Volcanism represented by the Northern Boisdale Hills volcanic unit took place in subaerial or shallow water conditions, and its relationship to the basin represented by the now-adjacent Bourinot belt is unclear. Similarity in the age of volcanic activity in the Northern Boisdale Hills to $c a$. 509 to $493 \mathrm{Ma}$ granitic plutonism in the Bras d'Or terrane that was possibly accompanied by low-
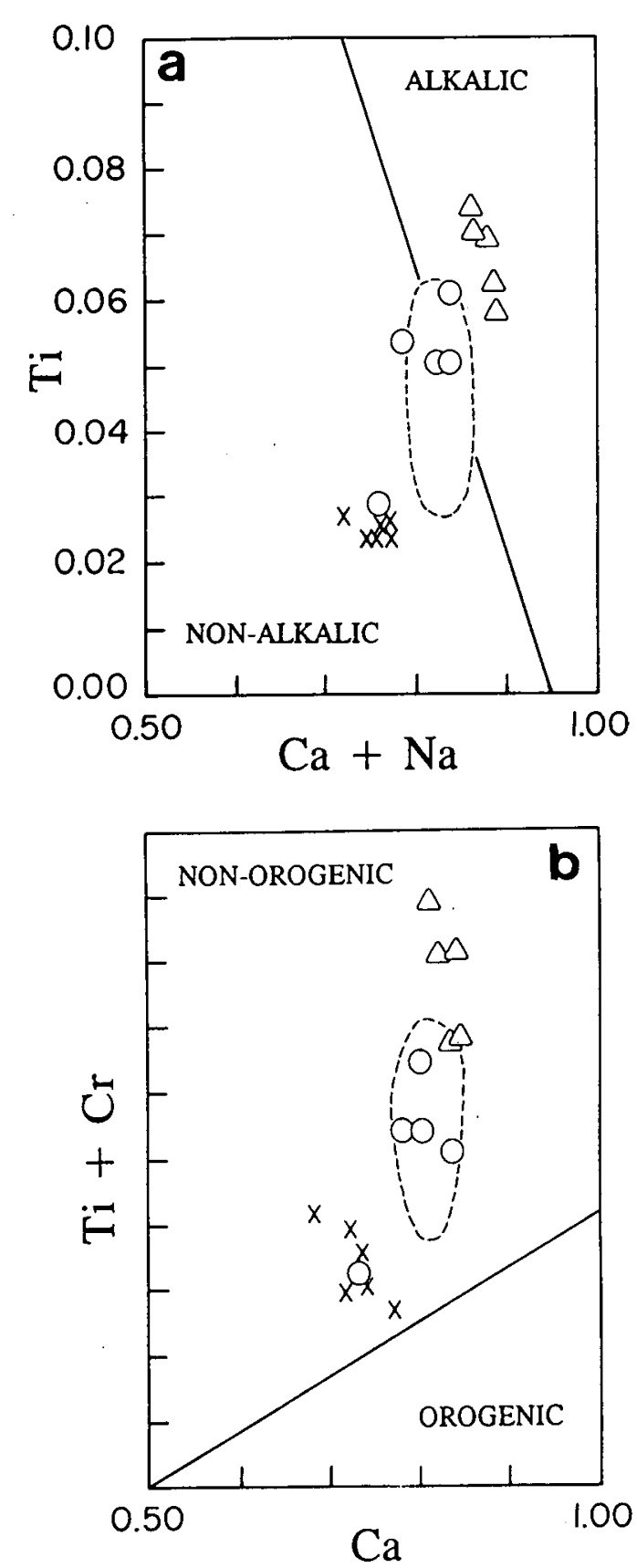

Fig. 11. Clinopyroxene analyses from the Bourinot belt plotted on the (a.) $\mathrm{Ti}-\mathrm{Ca}+\mathrm{Na}$ and (b.) $\mathrm{Ti}+\mathrm{Cr}-\mathrm{Ca}$ discrimination diagrams of Leterrier et al. (1982). Circles and triangles are analyses from sill samples 9 and 10 (Fig. 2; Table 2). X's are analyses from basaltic Long Island sample 14 (Fig. 4; Table 2). Fields outline majority of pyroxene compositions in samples from basalts of the Eskasoni Formation reported by Murphy et al. (1985).

pressure (high-heat-flow) metamorphism (Raeside and Barr, 1990) suggests a relationship, but the tectonic regime is enigmatic.

In conclusion, this study has demonstrated the complexities and uncertainties of geological relationships in the Bourinot belt, and in particular the major importance of faults in the belt, which had not been emphasized in previous work. New biostratigraphic studies are needed to try to better reconcile radiometric and palaeontological ages. Overall, the origin of the 
Bourinot belt, its regional correlatives, and the history of its development into its present configuration remain enigmatic.

\section{ACKNowledgements}

This project was funded by a Natural Sciences and Engineering Research Council operating grant to SMB. MLB is grateful to $M$. Villeneuve and the technical staff of the Geochronology Laboratory at the Geological Survey of Canada, Ottawa, for their help in producing the U-Pb analyses. MLB also thanks J.K. Mortensen for numerous discussions about the interpretation of the $\mathrm{U}-\mathrm{Pb}$ data. We thank the journal reviewers E. Landing and R.D. Hutchinson for their comments on the manuscript.

BARR, S.M. and RAEside, R.P. 1989. Tectonostratigraphic terranes in Cape Breton Island, Nova Scotia. Implications for the configuration of the northern Appalachian Orogen. Geology, 17, pp. 822825.

BARR, S.M. and SETTER, J.R.D. 1986. Petrology of granitoid rocks of the Boisdale Hills, central Cape Breton Island, Nova Scotia. Nova Scotia Department of Mines and Energy, Paper 84-1, 75 p.

BarR, S.M., DunNing, G.R., RAEside, R.P., and Jamieson, R.A. 1990. Contrasting U-Pb ages from plutons in the Bras d'Or and Mira terranes of Cape Breton Island, Nova Scotia. Canadian Journal of Earth Sciences, 27, pp. 1200-1208.

BARR, S.M., Bevier, M.L., White, C.E., and DoIg, R. 1992. Magmatic history of the Caledonia (Avalon) terrane of southern New Brunswick based on U-Pb zircon) geochronology. In New Brunswick Department of Natural Resources and Energy, Mineral Resources, Information Circular 92-1, pp. 4-5. Edited by S.A. Abbot.

BARR, S.M., White, C.E., and Macdonald, A.S. 1992. Revision of upper Precambrian - Cambrian stratigraphy, southeastern Cape Breton Island, Nova Scotia. In Current Research, Part D, Geological Survey of Canada, Paper 92-1D, pp. 21-26.

Bell, W.A. and Goranson, E.A. 1938. Sydney Sheet (West Half). Geological Survey of Canada, Department of Mines and Resources. Map 360A. Scale 1 inch to 1 mile.

BEvier, M.L. and BARR, S.M. 1990. U-Pb age constraints on the stratigraphy and tectonic history of the Avalon terrane, New Brunswick, Canada. Journal of Geology, 98, pp. 53-63.

Bevier, M.L., BarR, S.M., White, C.E., and Macdonald, A.S. 1993. $\mathrm{U}-\mathrm{Pb}$ geochronologic constraints on the volcanic evolution of the Mira (Avalon) terrane, southeastern Cape Breton Island, Nova Scotia. Canadian Journal of Earth Sciences, 30, pp. 1-10.

CAMERON, K.J. 1980. Geochemistry and petrogenesis of volcanic rocks from the Bourinot Group, Cape Breton Island, Nova Scotia. Unpublished B.Sc. thesis, Saint Mary's University, Halifax, Nova Scotia, 114 p.

Dunning, G.R., Barr, S.M., Raeside, R.P., and Jamieson, R.A. 1990. U.Pb zircon, titanite, and monazite ages in the Bras d'Or and Aspy terranes of Cape Breton Island, Nova Scotia: Implications for magmatic and metamorphic history. Geological Society of America Bulletin, 102, pp. 322-330.

FletCher, H. 1877. Report of the explorations and surveys in Cape Breton, Nova Scotia. In Geological Survey of Canada, Report of Progress for 1875-76, pp. 369-418.

GREenOUGH, J.D. and PAPEZJK, V.S. 1985. Petrology and geochemistry of Cambrian volcanic rocks from the Avalon Peninsula, Newfoundland. Canadian Journal of Earth Sciences, 22, pp. 1594-1601.

Greenough, J.D., Mccutcheon, S.R., and Papezjk, V.S. 1985. Petrology and geochemistry of Cambrian volcanic rocks from the Avalon
Zone in New Brunswick. Canadian Journal of Earth Sciences, 22, pp. 881-892.

Heaman, L.M. and Machado, N. 1992. Timing and origin of mid-continent rift alkaline magmatism, North America: Evidence from the Coldwell Complex. Contributions to Mineralogy and Petrology, 110, pp. 289-303.

Helmstaed, H. and Tella, S. 1972. Structural history of pre-Carboniferous rocks in parts of eastern Cape Breton Island. In Geological Survey of Canada, Report of Activities, Part A, Paper 72-1, pp. 7-10.

1973. Pre-Carboniferous structural history of southeast Cape Breton Island, Nova Scotia. Maritime Sediments, 9, pp. 88-99.

Henningsmoen, G. 1969. Short account of Cambrian and Tremadocian of Acado-Baltic province. In North Atlantic geology and continental drift: a symposium. Edited by M. Kay. American Association of Petroleum Geologists, Memoir 12, pp. 110-114.

Hutchinson, R.D. 1952. The stratigraphy and trilobite faunas of the Cambrian sedimentary rocks of Cape Breton Island, Nova Scotia. Geological Survey of Canada, Memoir 262, 124 p.

- 1962. Cambrian stratigraphy and trilobite faunas of southeastern Newfoundland. Geological Survey of Canada, Bulletin $88,156 \mathrm{p}$.

Johnson, S.C. and MCLeOd, M.J. 1994. Tectonic significance of the new River belt: a unique segment along the western margin of the Avalon Composite terrane, southern New Brunswick. Geological Society of America, 1994 Abstracts with Programs, 26, p. 26.

Johnson, S.C., McLeod, M.J., and KROGH, T.E. 1993. Geology and geochronology of the Fowle Lake area: evidence for Late Cambrian volcanism in southern New Brunswick. Atlantic Geology, 29, p. 83.

KePPIE, J.D. 1990. Comment on "Tectonostratigraphic terranes in Cape Breton Island, Nova Scotia: Implications for the configuration of the northern Appalachian orogen". Geology, 18, pp. 669-670.

KePPIE, J.D. and DallmeYeR, R.D. 1991. Contrasting U-Pb ages from plutons in the Bras d'Or terrane and Mira terranes on Cape Breton Island: Discussion. Canadian Journal of Earth Sciences, 28, pp. 1493-1494.

KePpie, J.D. and Dostal, J. 1980. Paleozoic volcanic rocks of Nova Scotia. In The Caledonides in the U.S.A. Edited by D.R. Wones. Virginia Polytechnic Institute and State University, Blacksburg, Virginia, Memoir 2, pp. 249-256.

KepPIE, J.D., Dallmeyer, R.D., and Murphy, J.B. 1990. Tectonic implications of ${ }^{40} \mathrm{Ar} /{ }^{39} \mathrm{Ar}$ hornblende ages from late Proterozoic-Cambrian plutons in the Avalon Composite Terrane, Nova Scotia, Canada. Geological Society of America Bulletin, 102 , pp. 516-528.

$\mathrm{K}_{\mathrm{ROGH}}, \mathrm{T}$.E. 1982. Improved accuracy of U.Pb ages by the creation of more concordant systems using an air abrasion technique. Geochimica et Cosmochimica Acta, 46, pp. 637-649.

Landing, E. 1991. Upper Precambrian through Lower Cambrian of Cape Breton Island: faunas, paleoenvironments, and stratigraphic revision. Journal of Paleontology, 65, pp. 507-595.

1994. Avalon - an insular continent by the latest Precambrian. Geological Society of America, 1994 Abstracts with Programs, 26, p. 31.

Leterrier, J., Maury, R.C., Thonon, P., Giraud, D., and Marchal, M. 1982. Clinopyroxene compositions as a method of the magmatic affinities of paleo-volcanic series. Earth and Planetary Science Letters, 59, pp. 139-154.

MatThew, G.F. 1903. Report of the Cambrian rocks of Cape Breton. Geological Survey of Canada, No. 797, p. 246.

- 1915. The physics of the Cambrian formation in eastern Canada, and the peculiarities of its faunas. The Royal Society of Canada, Proceedings and Transactions, third series, 8, pp. 69-85. 
Meschede, M. 1986. A method of discriminating between different types of mid-ocean ridge basalts and continental tholeiites with the $\mathrm{Nb}-\mathrm{Zr}-\mathrm{Y}$ diagram. Chemical Geology, 56, pp. 207-218.

Murphy, J.B., Cameron, K., Dostal, J., Keppie, J.D., and Hynes, A.J. 1985. Cambrian volcanism in Nova Scotia, Canada. Canadian Journal of Earth Sciences, 22, pp. 599-606.

Murphy, J.B., Keppie, J.D., Nance, R.D., and Dostal, J. 1990. The Avalon composite terrane of Nova Scotia. In Avalonian and Cadomian Geology of the North Atlantic. Edited by R.A. Strachan and G.K. Taylor. Blackee, Glasgow, pp. 195-213.

Palmer, A.R. 1983. The Decade of North American Geology geologic time scale. Geology, 11, pp. 503-504.

Parrish, R.R., Roddick, J.C., Loveridge, D., and Sullivan, R.W., 1987. Uranium-lead analytical techniques at the Geochronology laboratory, Geological Survey Canada. In Radiogenic age and isotopic studies, Report 1, Geological Survey of Canada, Paper 87-2, pp. 3-7.

Pearce, J.A. and CANN, J.R. 1973. Tectonic setting of basic volcanic rocks determined using trace element analysis. Earth and Planetary Science Letters, 28, pp. 459-469.

Pearce, J.A., Harris, N.B.W., and Tindle, A.G. 1984. Trace element discrimination diagrams for the tectonic interpretation of granitic rocks. Journal of Petrology, 25, pp. 856-983.

RAEside, R.P. and BARR, S.M. 1990. Geology and tectonic development of the Bras d'Or suspect terrane, Cape Breton Island, Nova Scotia. Canadian Journal of Earth Sciences, 27, pp. 1371-1381.
RoDDICK, J.C. 1987. Generalized numerical error analysis with applications to geochronology and thermodynamics. Geochimica et Cosmochimica Acta, 51, pp. 2129-2135.

SMITH, P.K. 1978. Geology of the Giant Lake area, southeastern Cape Breton Island, Nova Scotia. Nova Scotia Department of Mines and Energy, Paper 78-3, 21 p.

StaceY, J.S. and Kramers, J.D. 1975. Approximation of terrestrial lead isotope evolution by a two-stage model. Earth and Planetary Science Letters, 34, pp. 207-226.

StEIGER, R.H. and JĀGER, H. 1977. Subcommission on geochronology: convention on the use of decay constants in geo- and cosmochronology. Earth and Planetary Science Letters, 36, pp. 359-362.

Walcott, C.D. 1912. Cambrian brachiopods. United States Geological Survey, Monograph 60, 1235 p.

Weeks, F.J. 1954. Southeast Cape Breton Island, Nova Scotia. Geological Survey of Canada, Memoir 277, 112 p.

Williams, H. 1979. Appalachian orogen in Canada. Canadian Journal of Earth Sciences, 16, pp. 792-807.

WINCHESTER, J.A. and FLOYD, P.A. 1977. Geochemical discrimination of different magma series and their differentiation products using immobile elements. Chemical Geology, 20, pp. 321-355.

Young, G.A. 1913. George River. In Geological Survey of Canada Guide Book No. 1 - Excursions in Eastern Quebec and the Maritime Provinces, Part 2, pp. 266-276. 